Supporting information for

\title{
Maltose-Based Fluorinated Surfactants for Membrane-Protein Extraction and Stabilization
}

\author{
Moheddine Wehbie, ${ }^{\mathrm{a}}$ Kenechi Kanayo Onyia, ${ }^{\mathrm{b}, \mathrm{c}}$ Florian Mahler, ${ }^{\mathrm{b}}$ Aline Le Roy, ${ }^{\mathrm{d}}$ \\ Anaïs Deletraz, ${ }^{\mathrm{a}}$ Ilham Bouchemal, ${ }^{\mathrm{d}}$ Carolyn Vargas,${ }^{\mathrm{be}, \mathrm{e}, \mathrm{g}, \mathrm{g}}$ Jonathan Oyebamiji Babalola, ${ }^{\mathrm{c}}$ \\ Cécile Breyton, ${ }^{\mathrm{d}}$ Christine Ebel, ${ }^{\mathrm{d}}$ Sandro Keller, ${ }^{\mathrm{be}, \mathrm{f}, \mathrm{g}}$ Grégory Durand ${ }^{\mathrm{a} *}$
}

anstitut des Biomolécules Max Mousseron (UMR 5247 UM-CNRS-ENSCM) \& Avignon University, Equipe Chimie Bioorganique et Systèmes amphiphiles, 301 rue Baruch de Spinoza - 84916 AVIGNON cedex 9, France; bMolecular Biophysics, Technische Universität Kaiserslautern (TUK), Erwin-Schrödinger-Str. 13, 67663

Kaiserslautern, Germany;

${ }^{\mathrm{c} D e p a r t m e n t}$ of Chemistry, University of Ibadan, 200284 Ibadan, Nigeria;

dUniv. Grenoble Alpes, CNRS, CEA, CNRS, IBS, F-38000 Grenoble;

${ }^{\text {e} B i o p h y s i c s, ~ I n s t i t u t e ~ o f ~ M o l e c u l a r ~ B i o s c i e n c e s ~-~ I M B, ~ N A W I ~ G r a z, ~ U n i v e r s i t y ~ o f ~ G r a z, ~ H u m b o l d t s t r . ~ 50 / I I I, ~}$ 8010 Graz, Austria;

${ }^{f}$ Field of Excellence BioHealth, University of Graz, Graz, Austria;

gBioTechMed-Graz, Graz, Austria.

Corresponding Author. Grégory Durand. E-mail: gregory.durand@univ-avignon.fr ; Phone: +33 (0)4 90144445.

\begin{tabular}{|c|c|c|}
\hline Figure $\mathrm{S} 1$ & ITC, ${ }^{19} \mathrm{~F}$ NMR and surface tension data of $\mathrm{F}_{5} \mathrm{OM}$ & S2 \\
\hline Figure S2 & Analysis of sedimentation velocity experiments. & S2 \\
\hline Figure S3 & SAXS analysis of $\mathrm{F}_{5} \mathrm{OM}$ and $\mathrm{F}_{5} \mathrm{DM}$ & S3 \\
\hline Figure S4 & Concentration dependence of $\mathrm{F}_{5} \mathrm{OM}$ and $\mathrm{F}_{5} \mathrm{DM}$ micelle size from SAXS analysis & S4 \\
\hline Table S1 & Calculated scattering length density from Detergent Chemical Structure & S4 \\
\hline Table S2 & Analysis of $\mathrm{F}_{5} \mathrm{OM}$ and $\mathrm{F}_{5} \mathrm{DM}$ SAXS data in terms of a cylinder shape & S5 \\
\hline Figure S5 & Thermal denaturation of bR by differential scanning fluorimetry & S6 \\
\hline \multicolumn{2}{|c|}{ Material and Methods for BmrA and SpNox production, SpNox and BmrA activity assays } & S6 \\
\hline Figure S6 & Specific activity of BmrA and SpNox in $\mathrm{F}_{6} \mathrm{OM}, \mathrm{F}_{5} \mathrm{OM}$ and $\mathrm{F}_{5} \mathrm{DM}$ & S7 \\
\hline Figure S7 & ${ }^{1} \mathrm{H}-\mathrm{NMR}$ Spectrum of compound 2a & S8 \\
\hline Figure S8 & ${ }^{13} \mathrm{C}-\mathrm{NMR}$ Spectrum of compound $2 \mathrm{a}$ & S8 \\
\hline Figure S9 & MS Spectrum of compound 2a & S9 \\
\hline Figure S10 & ${ }^{1} \mathrm{H}-\mathrm{NMR}$ Spectrum of compound $2 \mathrm{~b}$ & S9 \\
\hline Figure S11 & ${ }^{13} \mathrm{C}-\mathrm{NMR}$ Spectrum of compound $2 \mathrm{~b}$ & S10 \\
\hline Figure S12 & MS Spectrum of compound 2b & S10 \\
\hline Figure S13 & ${ }^{1} \mathrm{H}-\mathrm{NMR}$ Spectrum of compound 3a & S11 \\
\hline Figure S14 & 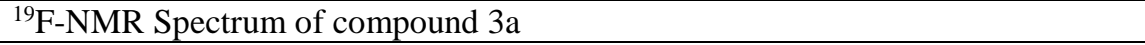 & S11 \\
\hline Figure S15 & ${ }^{13} \mathrm{C}-\mathrm{NMR}$ Spectrum of compound $3 \mathrm{a}$ & S12 \\
\hline Figure S16 & MS Spectrum of compound 3a & S12 \\
\hline Figure S17 & ${ }^{1} \mathrm{H}-\mathrm{NMR}$ Spectrum of compound 3b & S13 \\
\hline Figure S18 & ${ }^{19}$ F-NMR Spectrum of compound 3b & S13 \\
\hline Figure S19 & ${ }^{13} \mathrm{C}-\mathrm{NMR}$ Spectrum of compound $3 \mathrm{~b}$ & S14 \\
\hline Figure S20 & MS Spectrum of compound 3b & S14 \\
\hline Figure S21 & ${ }^{1} \mathrm{H}-\mathrm{NMR}$ Spectrum of compound $4 \mathrm{a}$ & S15 \\
\hline Figure S22 & ${ }^{{ }^{19} \mathrm{~F}-N M R}$ Spectrum of compound 4a & S15 \\
\hline Figure S23 & ${ }^{13} \mathrm{C}-\mathrm{NMR}$ Spectrum of compound $4 \mathrm{a}$ & S16 \\
\hline Figure S24 & MS Spectrum of compound 4a & S16 \\
\hline Figure S25 & ${ }^{1} \mathrm{H}-\mathrm{NMR}$ Spectrum of compound 4b & S17 \\
\hline Figure S26 & ${ }^{13}$ F-NMR Spectrum of compound $4 \mathrm{~b}$ & S17 \\
\hline Figure S27 & ${ }^{13} \mathrm{C}-\mathrm{NMR}$ Spectrum of compound $4 \mathrm{~b}$ & S18 \\
\hline Figure S28 & MS Spectrum of compound 4b & S18 \\
\hline \multicolumn{2}{|l|}{ References } & S19 \\
\hline
\end{tabular}



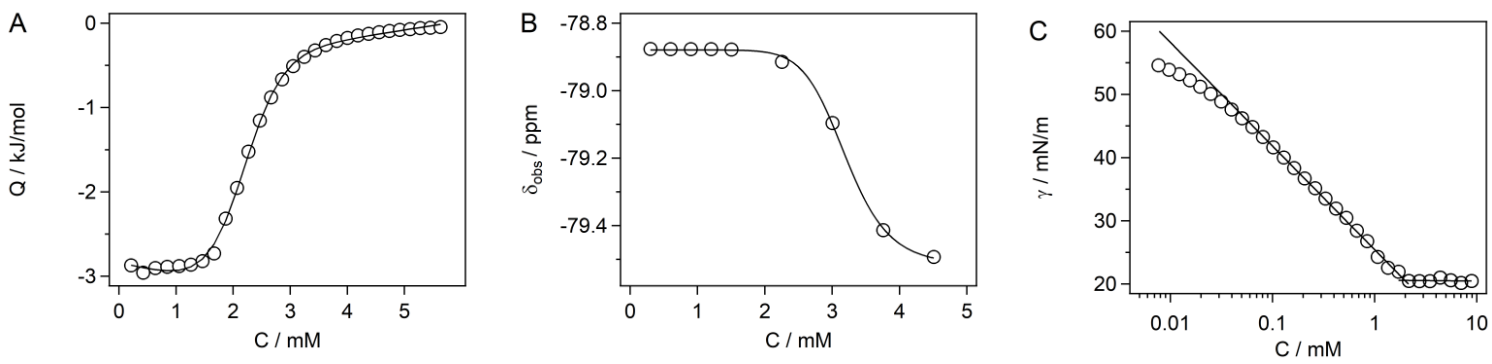

Figure S1. (A) ITC data for $\mathrm{F}_{5} \mathrm{OM}$. Shown are an experimental isotherm (open symbols) and a fit based on a generic sigmoidal function (solid line). (B) ${ }^{19} \mathrm{~F}$ NMR peak chemical shift, $\delta_{\text {obs }}$, versus $\mathrm{F}_{5} \mathrm{OM}$ concentration. We followed the signal of the terminal $\mathrm{CF}_{3}$ group of the chain. The solid line represents the nonlinear fit of the experimental points. ${ }^{1}$ (C) Surface tension versus $\mathrm{F}_{5} \mathrm{OM}$ concentration. The solid lines represent the linear fit of the experimental points and the intersection corresponds to the $\mathrm{cmc}$.
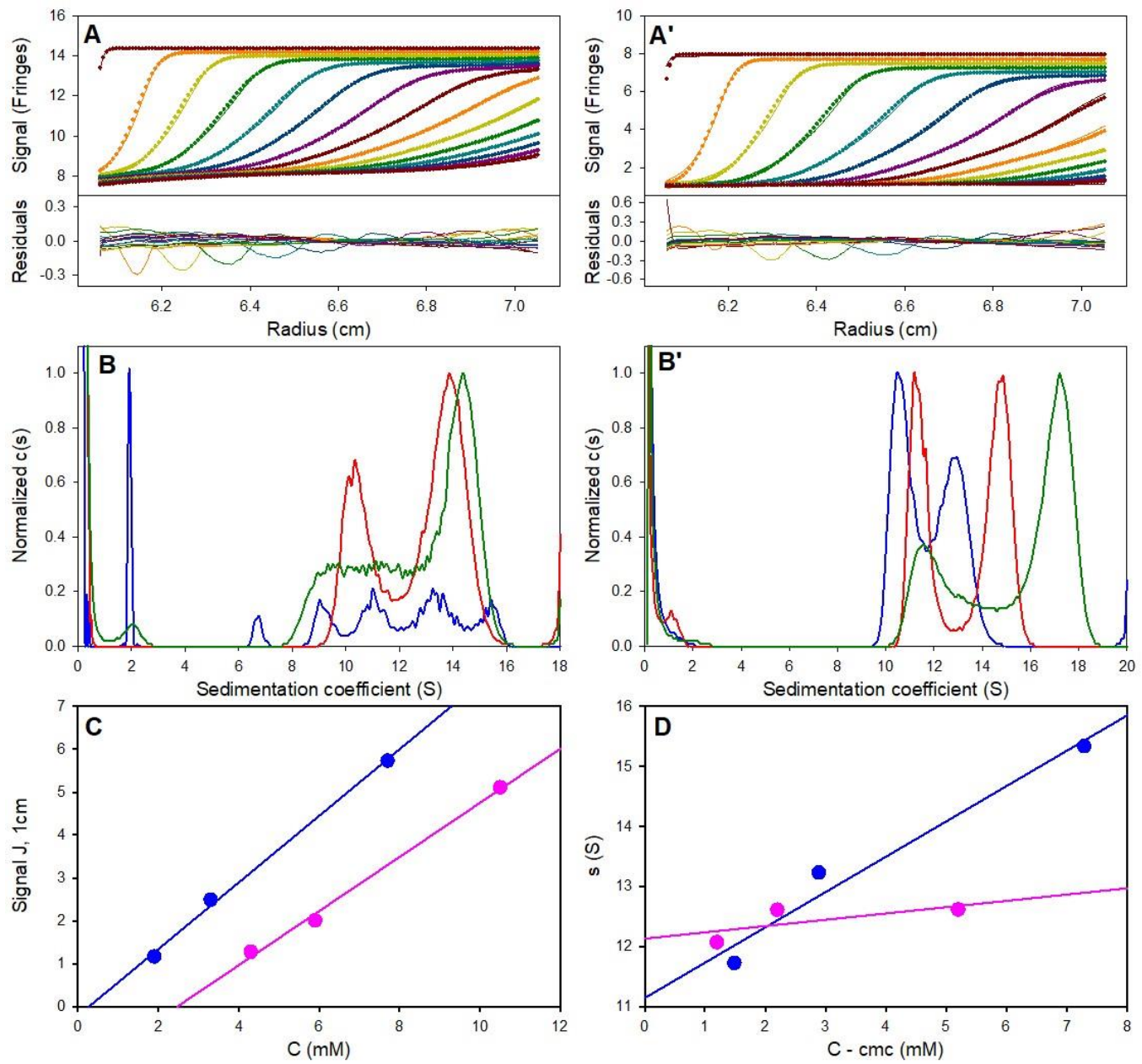

Figure S2. Analysis of sedimentation velocity experiments. Superposition of selected experimental and fitted sedimentation velocity profiles acquired every $\sim 10 \mathrm{~min}$ during $140 \mathrm{~min}$ at 130,000g (top) and residuals (bottom), for $\mathrm{F}_{5} \mathrm{OM}(\mathbf{A})$, and $\mathrm{F}_{5} \mathrm{DM}\left(\mathbf{A}^{\prime}\right)$, at 10.5 and $7.7 \mathrm{mM}$, respectively, in water at $20^{\circ} \mathrm{C}$, using interference optics, after subtraction of the systematic noises, and of the $c(s)$ analysis obtained for $\mathrm{F}_{5} \mathrm{OM}$ at $4.3 \mathrm{mM}$ (blue), 5.9 (red) and $10.5 \mathrm{mM}$ (green) (B), and $\mathrm{F}_{5} \mathrm{DM}$ at 1.9 (blue), 3.3 (red) and 7.7 (green) $\mathrm{mM}\left(\mathbf{B}^{\prime}\right)$. Plots of the micelle signal, in fringe shifts, versus surfactant concentration $(\mathbf{C})$, and of the mean $s$ for the micelle versus micelle concentration (D) for $\mathrm{F}_{5} \mathrm{OM}$ (pink) and $\mathrm{F}_{5} \mathrm{DM}$ (blue). The lines in $(\mathbf{C})$ and $(\mathbf{D})$ are linear fits. 

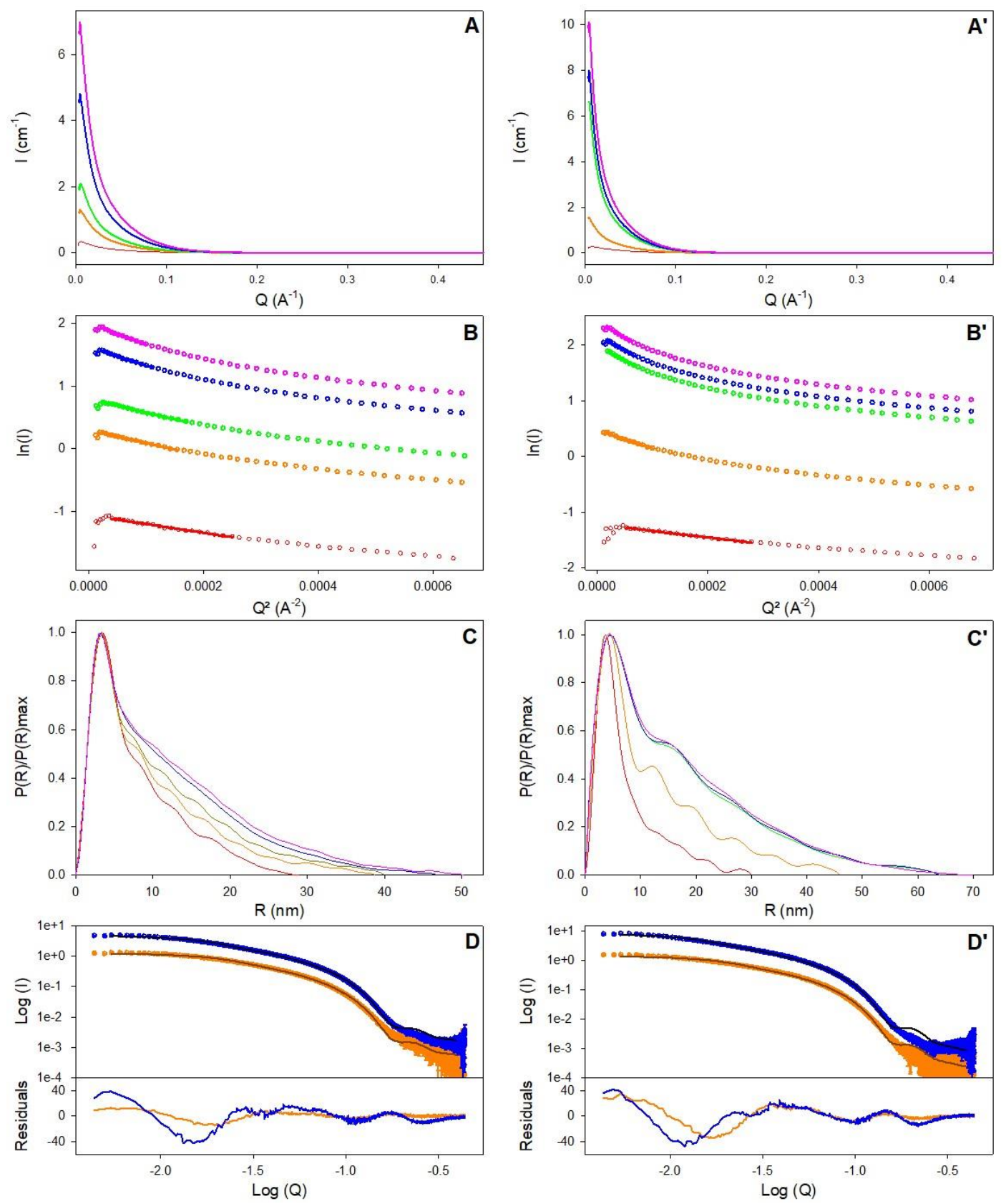

Figure S3. SAXS analysis of $\mathrm{F}_{5} \mathrm{OM}$ (left panels), and $\mathrm{F}_{5} \mathrm{DM}$ (right panels). SAXS patterns in absolute scale and after solvent subtraction (A, A'), Guinier plots (B, B'), pair distributions C, C'), and analysis in terms of cylinder (D, D'). $\mathrm{F}_{5} \mathrm{OM}$ concentrations: $4.0 \mathrm{mM}$ (red), $9.5 \mathrm{mM}$ (orange), $13.3 \mathrm{mM}$ (green), $23.6 \mathrm{mM}$ (blue) and $33.3 \mathrm{mM}$ (pink). $\mathrm{F}_{5} \mathrm{DM}$ concentrations: $2.9 \mathrm{mM}$ (red), $7.1 \mathrm{mM}$ (orange), $18.1 \mathrm{mM}$ (green), $24.8 \mathrm{mM}$ (blue) and $29.5 \mathrm{mM}$ (pink). 

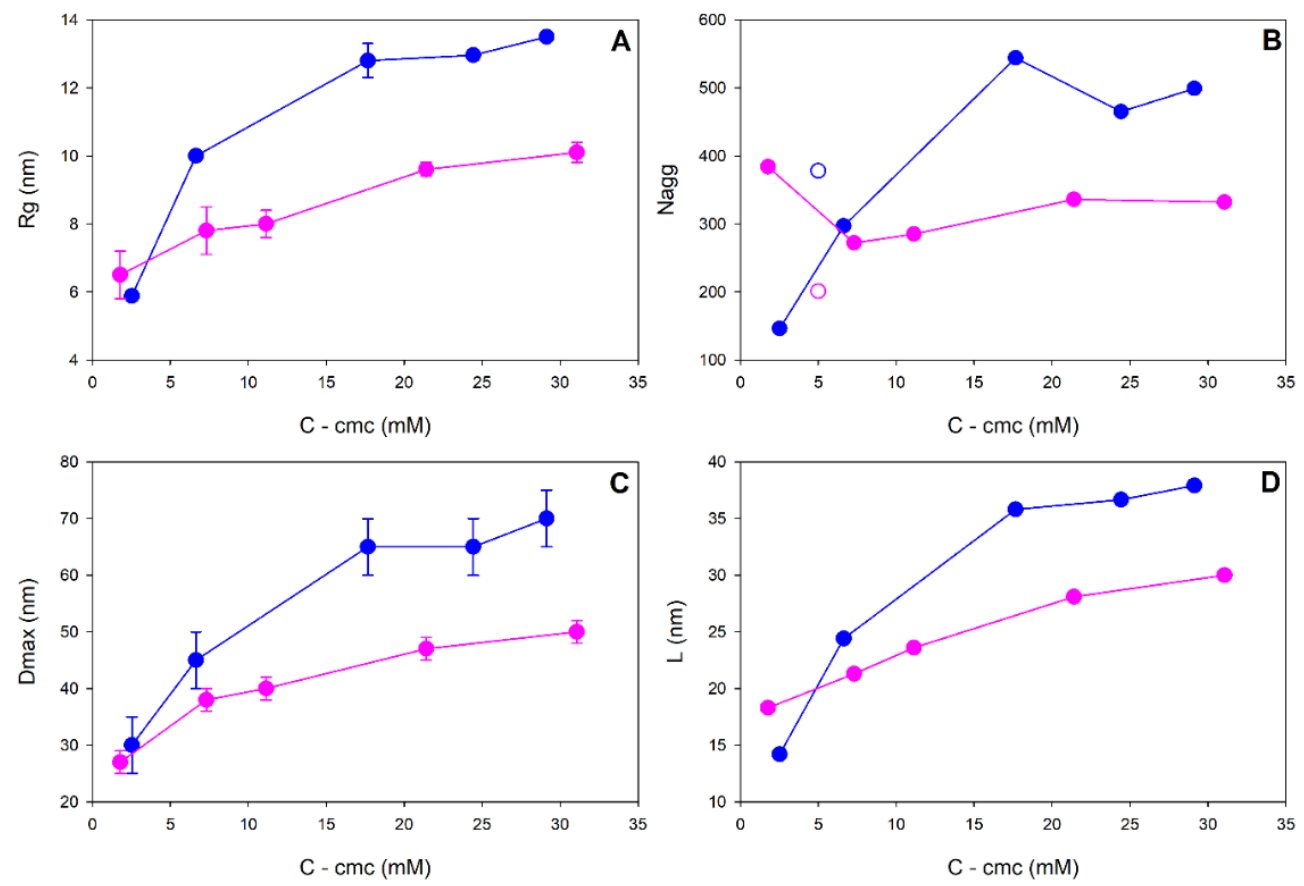

Figure S4. Concentration dependence of $\mathrm{F}_{5} \mathrm{OM}$ (pink) and $\mathrm{F}_{5} \mathrm{DM}$ (blue) micelle size from SAXS analysis. Circles on panel B represent $N_{\text {agg }}$ obtained combining sedimentation coefficients from AUC and hydrodynamic diameters from DLS. Note that at the largest concentrations, $R g$ and $N_{\text {agg }}$ may be underestimated, in view of the available Q-range.

Table S1. Calculated scattering length density from Detergent Chemical Structure.

\begin{tabular}{|c|c|c|}
\hline SAXS parameters $\left(20^{\circ} \mathrm{C}\right)$ & F5OM & F5DM \\
\hline Formula & $\mathrm{C} 20 \mathrm{H} 27 \mathrm{~F} 11011$ & $\mathrm{C} 22 \mathrm{H} 31 \mathrm{~F} 11 \mathrm{O} 11$ \\
\hline Tail Formula & C8H6F11 & $\mathrm{C} 10 \mathrm{H} 10 \mathrm{~F} 11$ \\
\hline Head Formula & $\mathrm{C} 12 \mathrm{H} 21011$ & $\mathrm{C} 12 \mathrm{H} 21011$ \\
\hline Molar Mass (Da) & 652,4 & 680,5 \\
\hline Tail Molar Mass (Da) & 311,1 & 339,2 \\
\hline Head Molar Mass (Da) & 341,3 & 341,3 \\
\hline $\operatorname{vbar}(\mathrm{mL} / \mathrm{g})$ & 0,571 & 0,595 \\
\hline Density $(\mathrm{g} / \mathrm{mL})$ & 1,750 & 1,681 \\
\hline Tail vbar (mL/g) & 0,509 & 0,562 \\
\hline Tail density $(\mathrm{g} / \mathrm{mL})$ & 1,965 & 1,779 \\
\hline Head vbar $(\mathrm{mL} / \mathrm{g})$ & 0,628 & 0,628 \\
\hline Head density $(\mathrm{g} / \mathrm{mL})$ & 1,592 & 1,592 \\
\hline $\operatorname{SLD}(\AA ̊-2)$ & $1,52 \mathrm{E}-05$ & $1,47 \mathrm{E}-05$ \\
\hline Tail SLD (̊̊-2) & $1,64 \mathrm{E}-05$ & $1,51 \mathrm{E}-05$ \\
\hline Head SLD (Å-2) & $1,44 \mathrm{E}-05$ & $1,44 \mathrm{E}-05$ \\
\hline Water SLD $(\AA \AA-2)$ & $9,43 \mathrm{E}-06$ & $9,43 \mathrm{E}-06$ \\
\hline (SLD - Water SLD) (̊̊-2) & $5,77 \mathrm{E}-06$ & $5,27 \mathrm{E}-06$ \\
\hline$\partial \rho \varepsilon \lambda / \partial c(\mathrm{~cm} / \mathrm{g})$ & $3,30 E+10$ & $3,14 \mathrm{E}+10$ \\
\hline
\end{tabular}

vbar: partial specific volume calculated from chemical structure, according to Durchschlag and Zipper ${ }^{2-3}$

SLD: scattering length density. They are calculated using the calculator of SASVIEW (www.sasview.org), from formulae and vbars, at $\lambda=0.9919 \AA . \partial \rho_{\mathrm{e} e} / \partial \mathrm{c}=(\mathrm{SLD}-$ Water SLD $) * v b a r$ 
Table S2. Analysis of $\mathrm{F}_{5} \mathrm{OM}$ and $\mathrm{F}_{5} \mathrm{DM}$ SAXS data in terms of a cylinder shape.

\begin{tabular}{|c|c|c|c|c|c|}
\hline & \multicolumn{5}{|c|}{$\mathrm{F}_{5} \mathrm{DM}$ Conc $\mathrm{mM}$} \\
\hline & 29.5 & 24.8 & 18.1 & 7.1 & 2.9 \\
\hline Scale (v:v) & 0.012 & 0.01 & 0.007 & 0.003 & 0.001 \\
\hline $\mathrm{Bg}(1 / \mathrm{cm})$ & 0.001 & 0.0007 & 0.001 & 0.0002 & 0.0002 \\
\hline sld (1e-6/Ang^2) & $13.02+/-0.00$ & $12.40+/-0.00$ & $13.29+/-0.00$ & $12.70+/-0.00$ & $\begin{array}{c}12.57+/- \\
0.00\end{array}$ \\
\hline $\begin{array}{l}\text { sld solvent (1e- } \\
6 / \text { Ang^}^{\wedge} \text { ) }\end{array}$ & \multicolumn{5}{|c|}{$\underline{9.43}$} \\
\hline Radius (Ang) & $22.35+/-0.00$ & $22.40+/-0.00$ & $22.46+/-0.00$ & $\begin{array}{c}22.42+/- \\
0.01\end{array}$ & $\begin{array}{c}23.04+/- \\
0.02\end{array}$ \\
\hline Lenght (Ang) & $\begin{array}{c}378.65+/- \\
0.20\end{array}$ & $\begin{array}{c}366.52+/- \\
0.26 \\
\end{array}$ & $\begin{array}{c}357.91+/- \\
0.27\end{array}$ & $\begin{array}{c}243.90+/- \\
0.23\end{array}$ & $\begin{array}{c}142.16+/- \\
0.28\end{array}$ \\
\hline RDP & \multicolumn{5}{|c|}{$\underline{0.15}$} \\
\hline LDP & \multicolumn{5}{|c|}{$\underline{0,00}$} \\
\hline Chi2 & 149,6 & 78,5 & 76,5 & 47,9 & 9,6 \\
\hline Npts (Fit) & \multicolumn{5}{|c|}{929} \\
\hline Npts & \multicolumn{5}{|c|}{1042} \\
\hline & \multicolumn{5}{|c|}{$\mathrm{F}_{5} \mathrm{OM}$ Conc $\mathrm{mM}$} \\
\hline & 33.3 & 23.6 & 13.3 & 9.5 & 4 \\
\hline Scale (v:v) & $\underline{0.0113}$ & $\underline{0.0077}$ & $\underline{0.0039}$ & $\underline{0.0025}$ & $\underline{0.0004}$ \\
\hline $\mathrm{Bg}(1 / \mathrm{cm})$ & $\underline{0.002}$ & $\underline{0.0015}$ & $\underline{0.0007}$ & $\underline{0.0005}$ & $\underline{0.001}$ \\
\hline sld (1e-6/Ang^2) & $13.38+/-0.00$ & $\begin{array}{c}13.52+/- \\
0.00\end{array}$ & $13.57+/-0.00$ & $13.63+/-0.00$ & $15.04+/-0.00$ \\
\hline $\begin{array}{l}\text { sld solvent (1e- } \\
\left.6 / \mathrm{Ang}^{\wedge} 2\right)\end{array}$ & \multicolumn{5}{|c|}{$\underline{9.43}$} \\
\hline Radius (Ang) & $19.34+/-0.00$ & $19.34+/-0.00$ & $19.34+/-0.00$ & $19.29+/-0.01$ & $19.95+/-0.02$ \\
\hline Lenght (Ang) & $\begin{array}{c}300.12+/- \\
0.18 \\
\end{array}$ & $\begin{array}{c}281.15+/- \\
0.14 \\
\end{array}$ & $\begin{array}{c}236.37+/- \\
0.17 \\
\end{array}$ & $\begin{array}{c}212.83+/- \\
0.32 \\
\end{array}$ & $\begin{array}{c}182.95+/- \\
0.52 \\
\end{array}$ \\
\hline RDP & \multicolumn{5}{|c|}{$\underline{0.15}$} \\
\hline LDP & \multicolumn{5}{|c|}{$\underline{0}$} \\
\hline Chi2 & 61.06 & 73.93 & 34.97 & 10.51 & 5.17 \\
\hline Npts (Fit) & \multicolumn{5}{|c|}{929} \\
\hline Npts & \multicolumn{5}{|c|}{1042} \\
\hline
\end{tabular}

The data were analyzed separately for each sample, with the program SAS View (4.2.1), using the cylinder model. The $\mathrm{Q}$ range for fit was $0.004-0.44 \AA^{-1}$. Underlined values are fixed. Scale: concentration (vol/vol); $\mathrm{Bg}$ : background; sld: scattering length density; radius: cylinder radius; length: cylinder length; RDP: radius polydispersity; LDP : length polydispersity; Npts: number of points. 


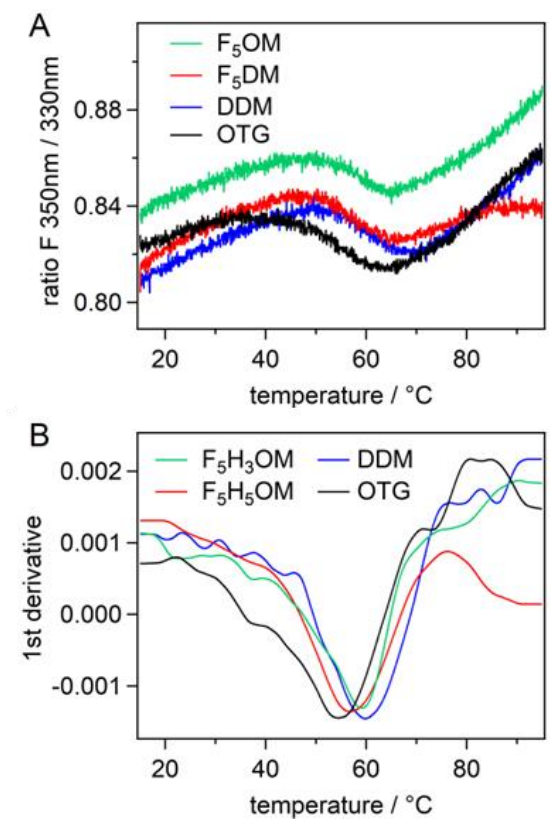

Figure S5. Thermal denaturation of $b R$ by differential scanning fluorimetry. (A) Ratio of the fluorescence emitted at 350 and $330 \mathrm{~nm}$, and (B) derivative for bR at $0.14 \mathrm{mg} \mathrm{mL}^{-1}$, incubated in the presence of $\mathrm{F}_{5} \mathrm{OM}$ at $\mathrm{cmc}+2 \mathrm{mM}$ (green), $\mathrm{F}_{5} \mathrm{DM}$ at $\mathrm{cmc}+2 \mathrm{mM}$ (red), DDM at cmc $+0.2 \mathrm{mM}$ (blue), OTG at $\mathrm{cmc}+2 \mathrm{mM}$ (black).

BmrA and SpNox production. Overexpression and purification of BmrA at $\approx 1.5 \mathrm{mg} / \mathrm{mL}$ were done according to Mathieu et al. ${ }^{4}$ with minor modifications: Solubilization in $1 \%$ DDM; elution from NiNTA and dialysis in Hepes-KOH pH $850 \mathrm{mM}$, glycerol $10 \%, \mathrm{NaCl} 100 \mathrm{mM}$ (buffer A) with $0.1 \%(2 \mathrm{mM})$ or $0.01 \%$ DDM. SpNOX was overexpressed and purified at $1 \mathrm{mg} / \mathrm{mL}$ in $50 \mathrm{mM}$ Tris $\mathrm{pH} \mathrm{7,300} \mathrm{mM} \mathrm{NaCl}, 10 \mu \mathrm{M}$ FAD (buffer B) with $0.3 \mathrm{mM}$ DDM, as previously described $^{5}$, except solubilisation was done in $7.4 \mathrm{mM}$ DDM. A final 6-times concentration step was done by ultrafiltration with $50 \mathrm{kDa}$ cut off (Amicon® Ultra-4 Centrifugal Filter Units). Concentrations of BmrA and SpNox were determined at $280 \mathrm{~nm}$.

SpNox activity assays. Purified SpNox was incubated $1 \mathrm{~h}$ at $4{ }^{\circ} \mathrm{C}$ with His60 Ni Superflow resin (Clontech), which had been equilibrated with buffer B with $0.3 \mathrm{mM} \mathrm{DDM}$. The resin with bound SpNox was then washed with buffer B containing each surfactant at cmc $+1 \mathrm{mM}$, cmc + $2 \mathrm{mM}$ or $\mathrm{cmc}+5 \mathrm{mM}$. Then elution in the new surfactant was done by $300 \mathrm{mM}$ Imidazol in the same buffer. Finally, the imidazol was removed using solvent exchange columns (PD spintrapTM G-25, GE Healthcare). Activity assays are described in Breyton et al. ${ }^{5}$ and were performed in triplicate. A dilution protocol was assayed for further studies: SpNox activity was followed by hourly measurements, after a 10-time dilution in Buffer B with two surfactants. In $\mathrm{DDM}$ at $\mathrm{cmc}+2 \mathrm{mM}$, activity decreased moderately with time $(\approx 25 \%$ in 8 hours $)$. In $\mathrm{F}_{5} \mathrm{OM}$ at $\mathrm{cmc}+1 \mathrm{mM}$, activity decreased with time, and remained $\approx$ constant between 2 and 8 hours of incubation. Thus the simpler dilution protocol with a ten-time dilution, and $2 \mathrm{~h}$ incubation, could have been used. We measured specific activities of SpNox in DDM at $\mathrm{cmc}+1,2$ or 5 $\mathrm{mM}$, of 4.1, 3.3, and $3.4( \pm 10 \%)$ mol Cyt $\mathrm{c}$ reduced $\mathrm{s}^{-1} \mathrm{~mol}^{-1}$ SpNox, smaller but in line with Breyton et al. ${ }^{5}$

BmrA activity assays. Two protocols for solvent exchange were used, both at $4{ }^{\circ} \mathrm{C}$ in buffer A. 1: by affinity chromatography, using $50 \mu \mathrm{L}$ dry volume Ni-NTA (His60 Ni Superflow Resin, Clontech) and $100 \mu \mathrm{L} \mathrm{BmrA}$ at $1.5 \mathrm{mg} / \mathrm{mL}$ in DDM $0.1 \%$, allowing to recover, after solvent 
exchange (Spin Trap G25, GE Healthcare), $140 \mu \mathrm{L}$ of BmrA at $0.5 \mathrm{mg} / \mathrm{mL}$ in buffer A with the final surfactant. 2: by dilution, BmrA at $1.2 \mathrm{mg} / \mathrm{mL}$ in $0.01 \% \mathrm{DDM}$ was diluted at $0.2 \mathrm{mg} / \mathrm{mL}$ with the final surfactant, and incubated $1 \mathrm{~h} 30$ on ice. Then $50 \mu \mathrm{L}(10 \mu \mathrm{g} \mathrm{BmrA}, 3-4 \mu \mathrm{g}$ from Bradford protein assay) were diluted into $200 \mu \mathrm{L}$ of mix (final volume) for each activity assay. With the hypothesis of $1 \mathrm{~g}$ of DDM bound to $1 \mathrm{~g}$ of BmrA, residual DDM was estimated as 0.6 cmc $(0.25 \mathrm{cmc}$ considering Bradford protein assay). BrmA ATPase activities were measured in Hepes- $\mathrm{KOH} 50 \mathrm{mMpH}$ 8, the final surfactant, $10 \mathrm{mM} \mathrm{MgCl}_{2}, 4 \mathrm{mM}$ phosphoenolpyruvate, $0.3 \mathrm{mM}$ NADH, $32 \mu \mathrm{g} / \mathrm{mL}$ of lactate deshydrogenase, $60 \mu \mathrm{g} / \mathrm{mL}$ pyruvate kinase, $10 \mathrm{mM}$ ATP, in 96-well micro test plates, at $37{ }^{\circ} \mathrm{C}$, using the microplate reader CLARIOstar (BMG LABTECH). This setup allows measuring six BmrA samples without significant BmrAindependent ATP hydrolysis, each BmrA measure being proceeded by a blank without BmrA. ATP $(20 \mu \mathrm{L})$ is injected and NADH oxidation is recorded at $340 \mathrm{~nm}$ during $10 \mathrm{~min}$ on each well successively. The activity, in nM NADH $\min ^{-1} \mu \mathrm{g}^{-1} \mathrm{BmrA}$, with BmrA estimated from Bradford protein assay, was calculated from the kinetics of A340, after blank subtraction. We measured specific activities of BmrA in $2 \mathrm{mM}$ DDM of $0.5 \pm 0.15 \mu \mathrm{mol}$ ATP hydrolyzed $\mathrm{min}^{-1} \mathrm{mg}^{-1}$ $\mathrm{BmrA}$ in the same order of magnitude of published value of $0.8 \pm 0.1 \mu \mathrm{mol}$ ATP hydrolyzed $\min ^{-1} \mathrm{mg}^{-1} \mathrm{BmrA}^{5}$

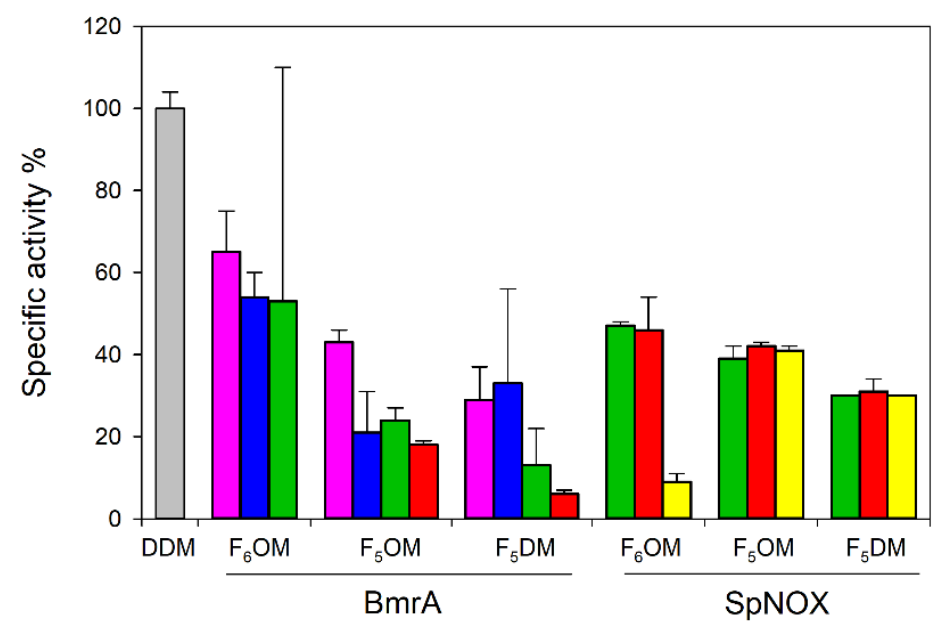

Figure S6. Specific Activity of BmrA and SpNOX in $\mathrm{F}_{6} \mathrm{OM}, \mathrm{F}_{5} \mathrm{OM}$ and $\mathrm{F}_{5} \mathrm{DM}$ at: $\mathrm{cmc}+0.2 \mathrm{mM}$ (pink), $\mathrm{cmc}+0.5 \mathrm{mM}$ (blue), cmc $+1 \mathrm{mM}$ (green), $\mathrm{cmc}+2 \mathrm{mM}$ (red), cmc $+5 \mathrm{mM}$ (yellow). Standard deviations were determined from triplicates experiments. Specific activity is normalized at $100 \%$ for measurement in cmc $+2 \mathrm{mM}$ DDM. Surfactant exchange was done by dilution, except for BmrA in surfactants at $\mathrm{cmc}+2 \mathrm{mM}$, where exchange was done by affinity chromatography. For BmrA in surfactants at $\mathrm{cmc}+0.2 \mathrm{mM}$, the two protocols were used and gave results within the error bar. 


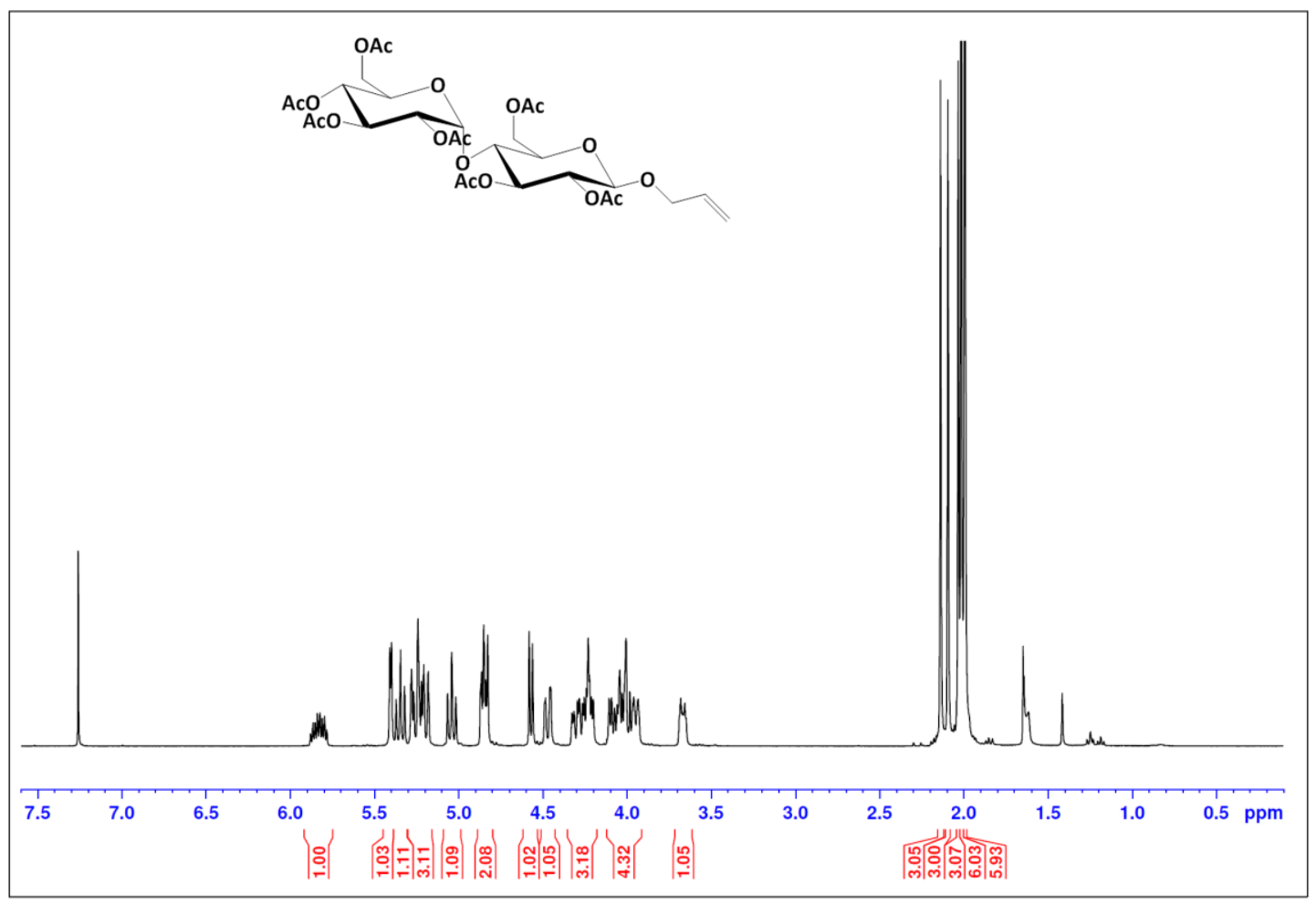

Figure S7. ${ }^{1} \mathrm{H}-\mathrm{NMR}$ spectrum of compound $\mathbf{2 a}$ in $\mathrm{CDCl}_{3}$.

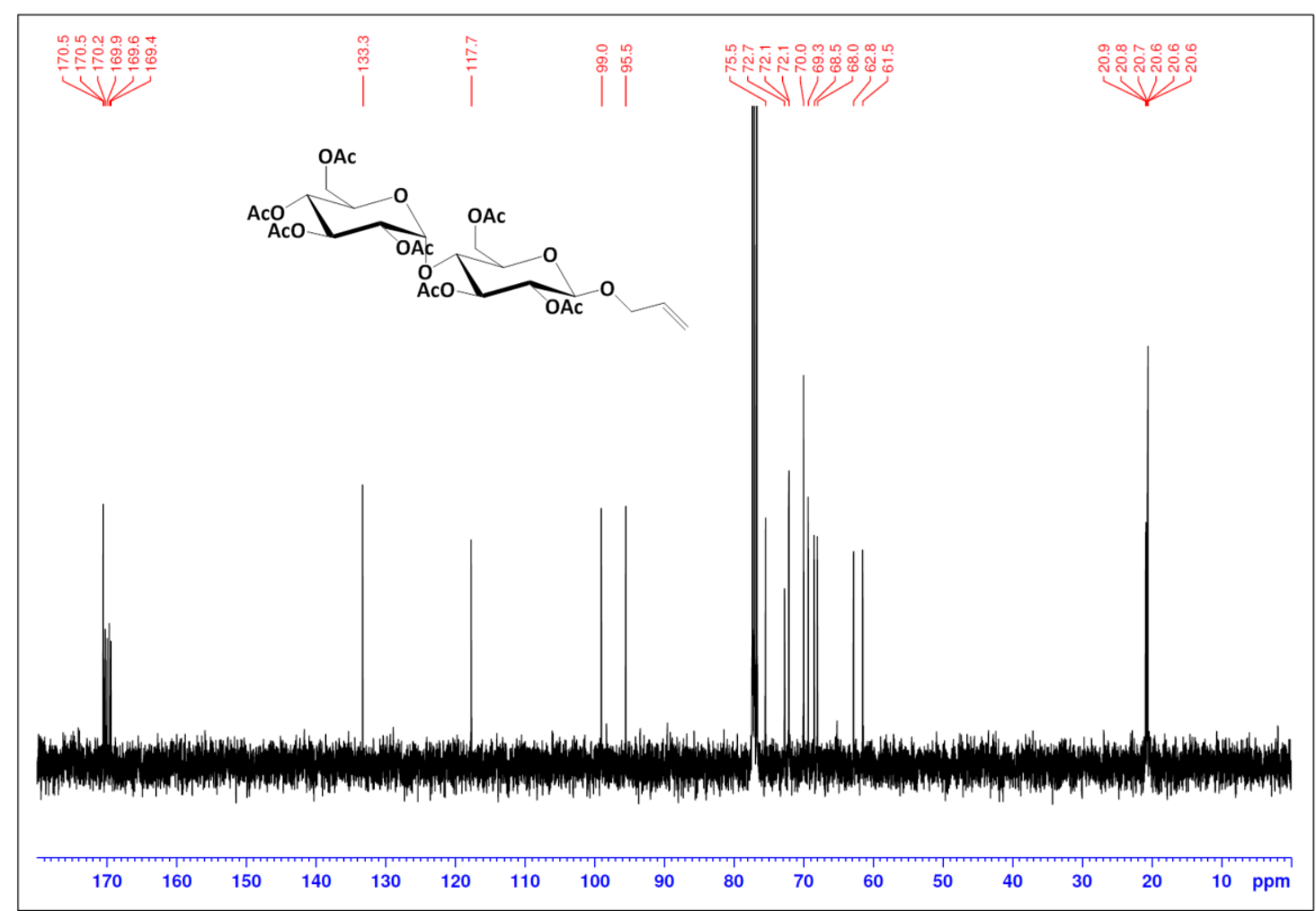

Figure S8. ${ }^{13} \mathrm{C}-\mathrm{NMR}$ spectrum of compound $\mathbf{2 a}$ in $\mathrm{CDCl}_{3}$. 


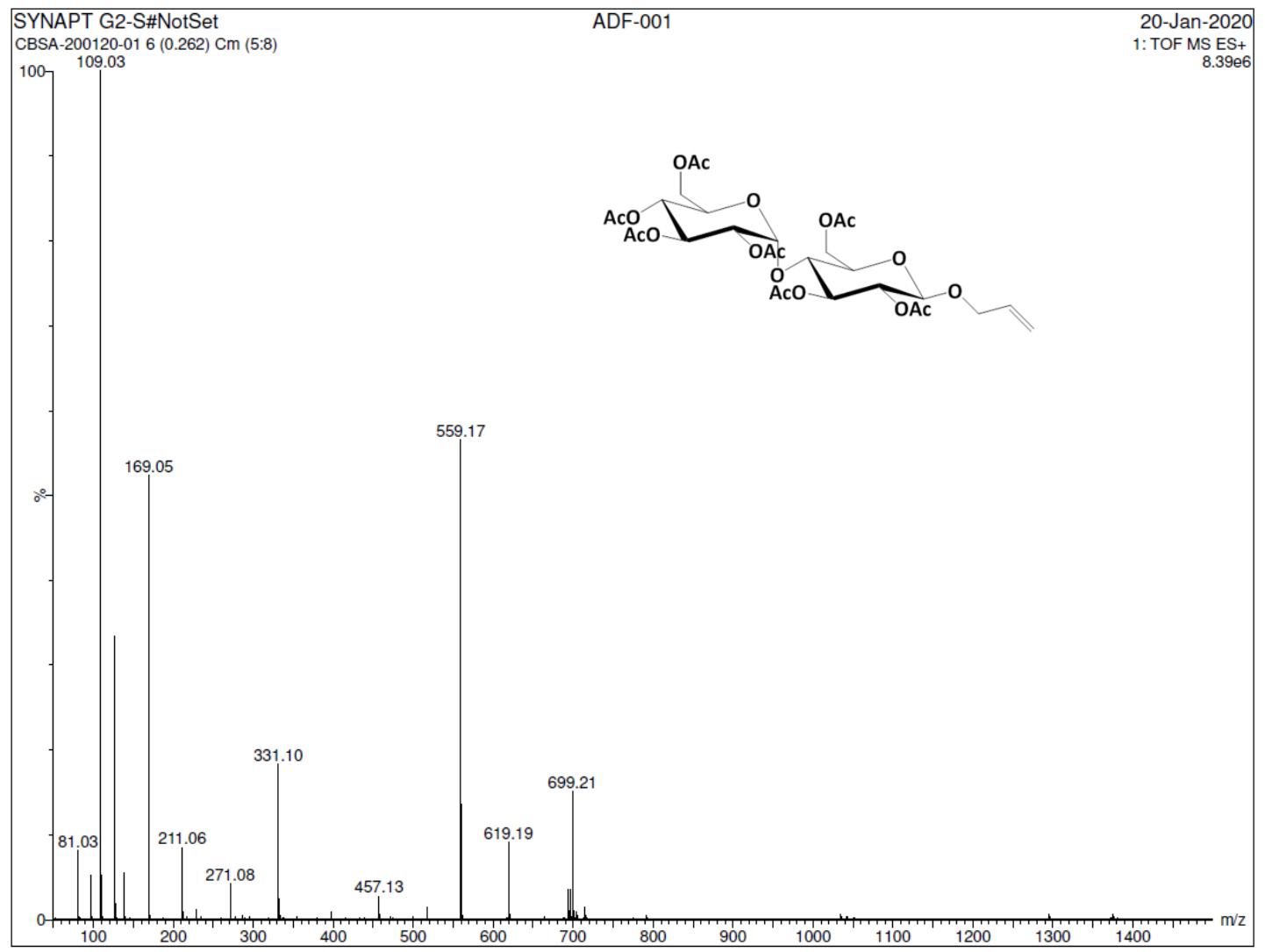

Figure S9. MS Spectrum of compound 2a.

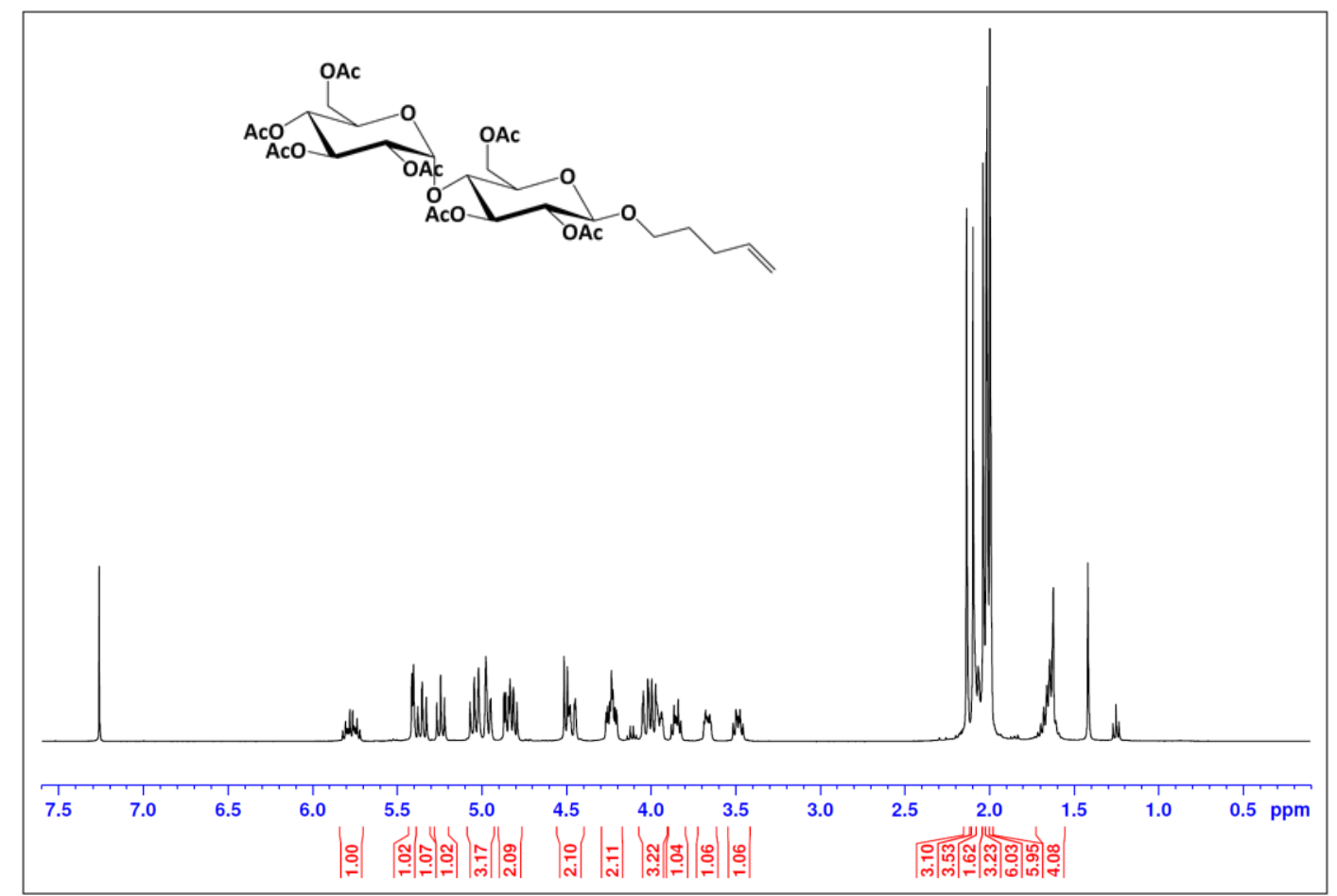

Figure S10. ${ }^{1} \mathrm{H}-\mathrm{NMR}$ spectrum of compound $\mathbf{2 b}$ in $\mathrm{CDCl}_{3}$. 


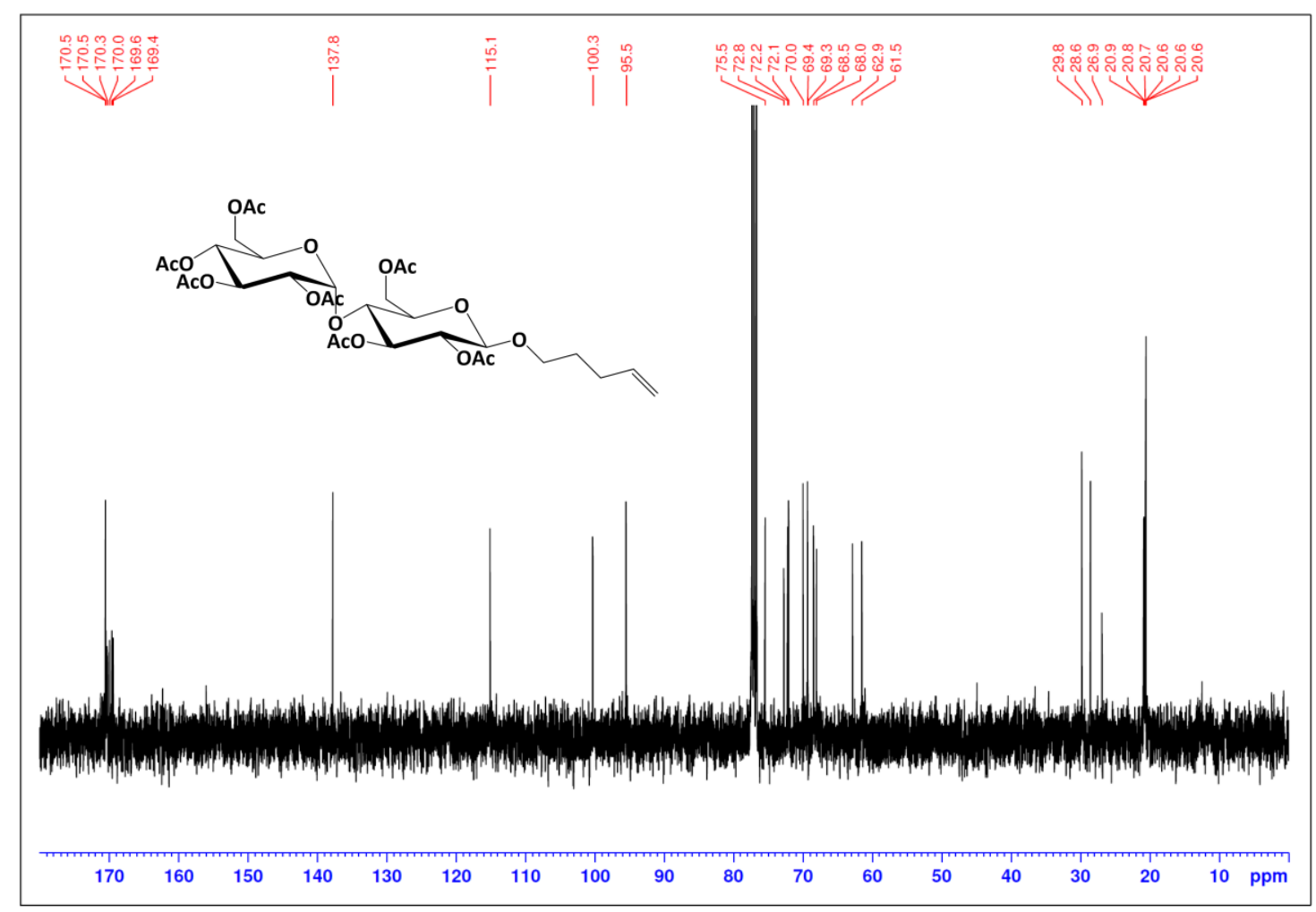

Figure S11. ${ }^{13} \mathrm{C}-\mathrm{NMR}$ spectrum of compound $\mathbf{2 b}$ in $\mathrm{CDCl}_{3}$.

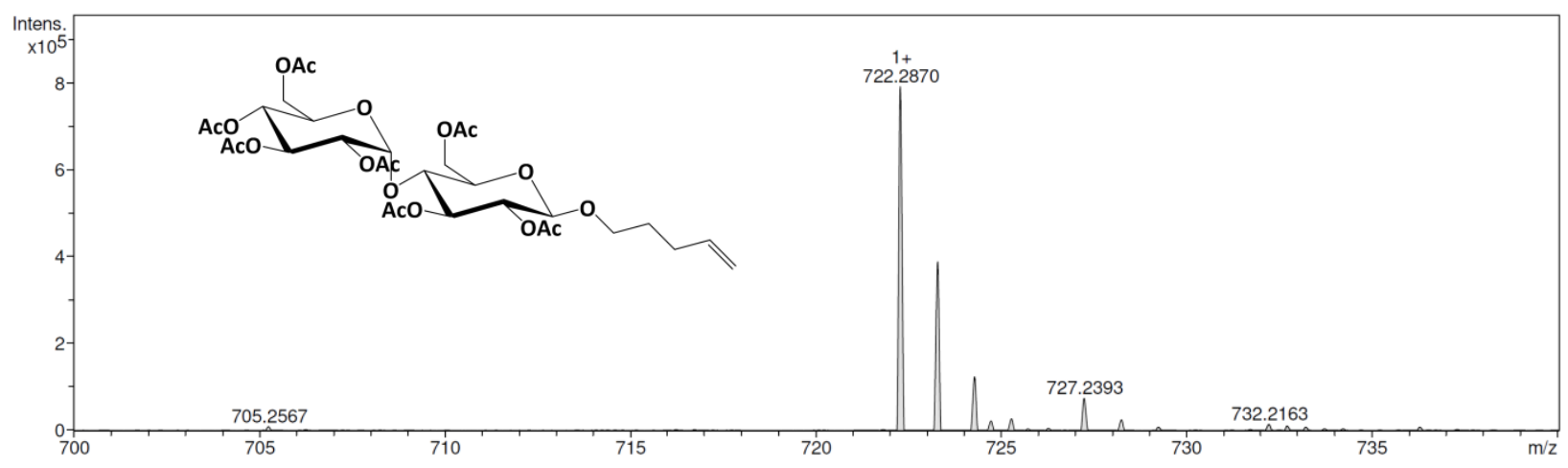

Figure S12. MS Spectrum of compound 2b. 


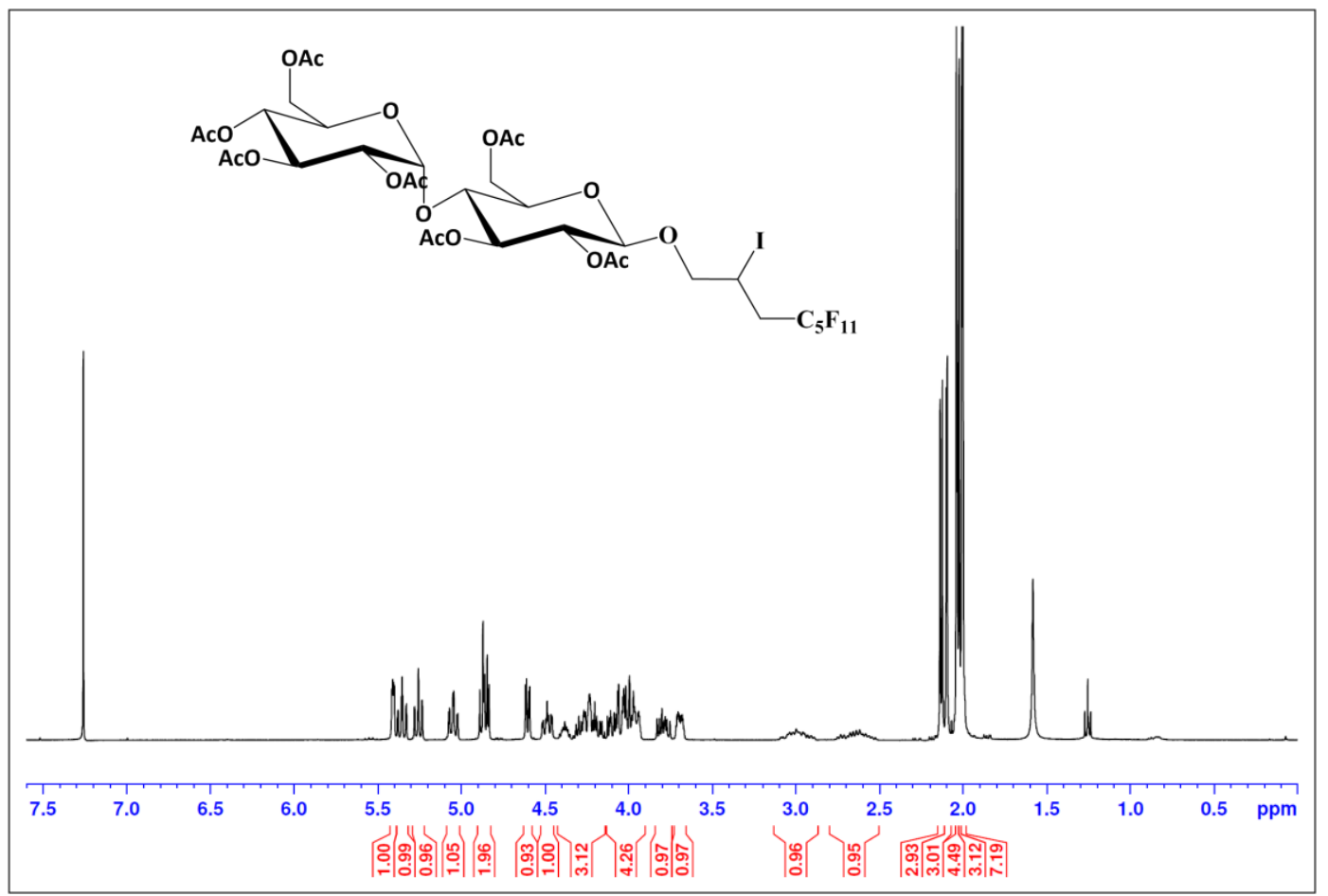

Figure S13. ${ }^{1} \mathrm{H}-\mathrm{NMR}$ spectrum of compound $\mathbf{3 a}$ in $\mathrm{CDCl}_{3}$.

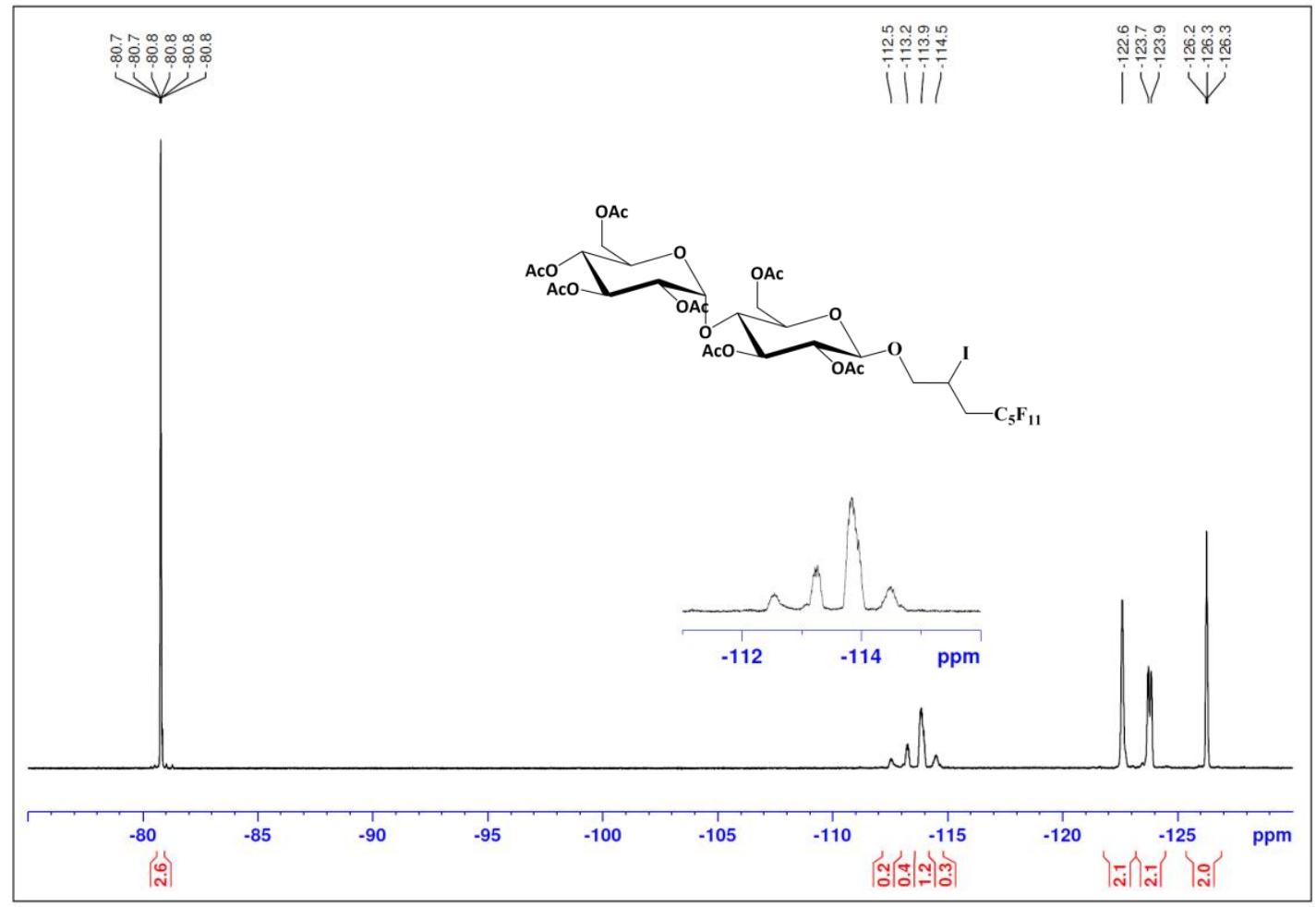

Figure S14. ${ }^{19} \mathrm{~F}-\mathrm{NMR}$ spectrum of compound $\mathbf{3 a}$ in $\mathrm{CDCl}_{3}$. 


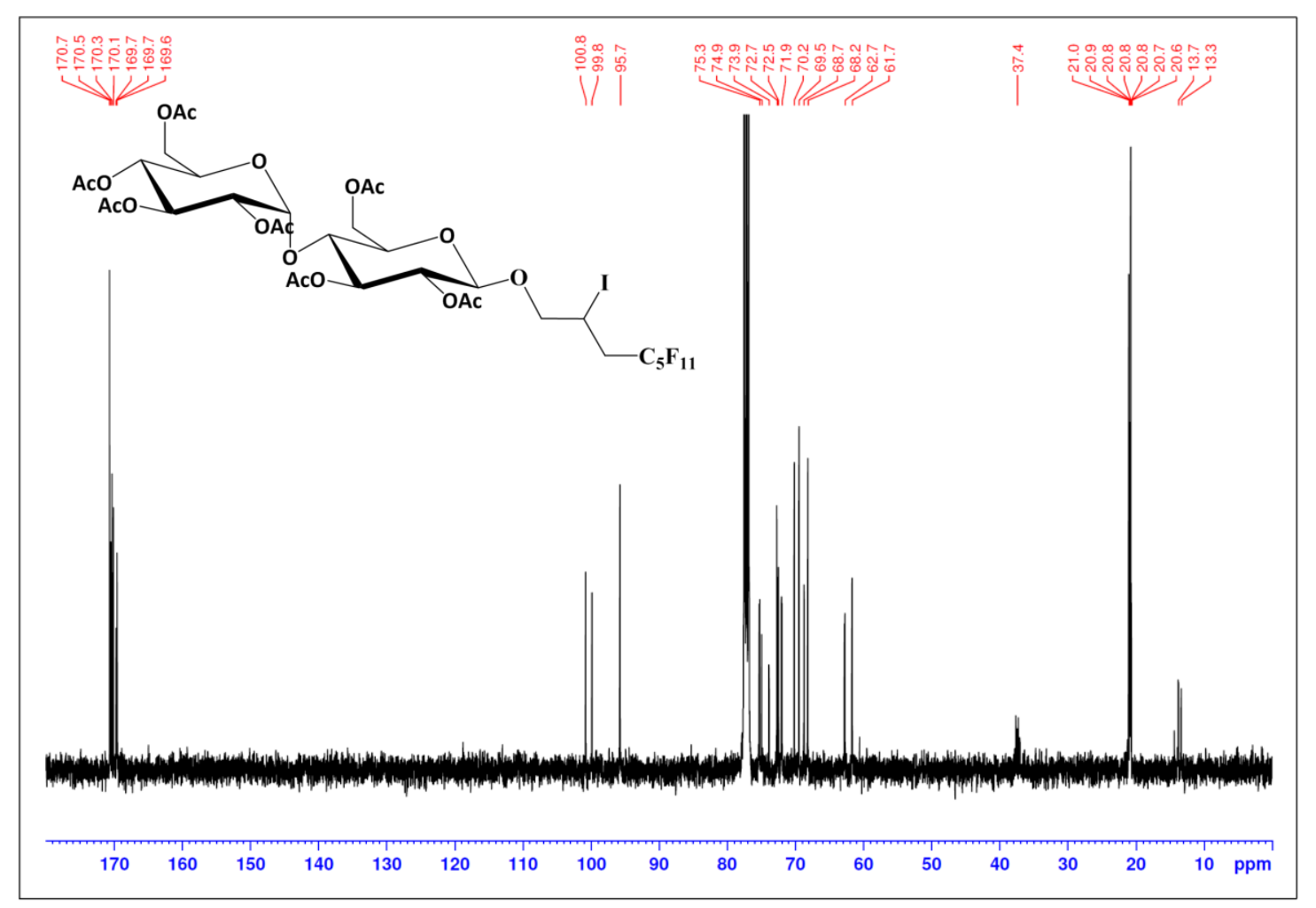

Figure S15. ${ }^{13} \mathrm{C}$-NMR spectrum of compound $\mathbf{3 a}$ in $\mathrm{CDCl}_{3}$.

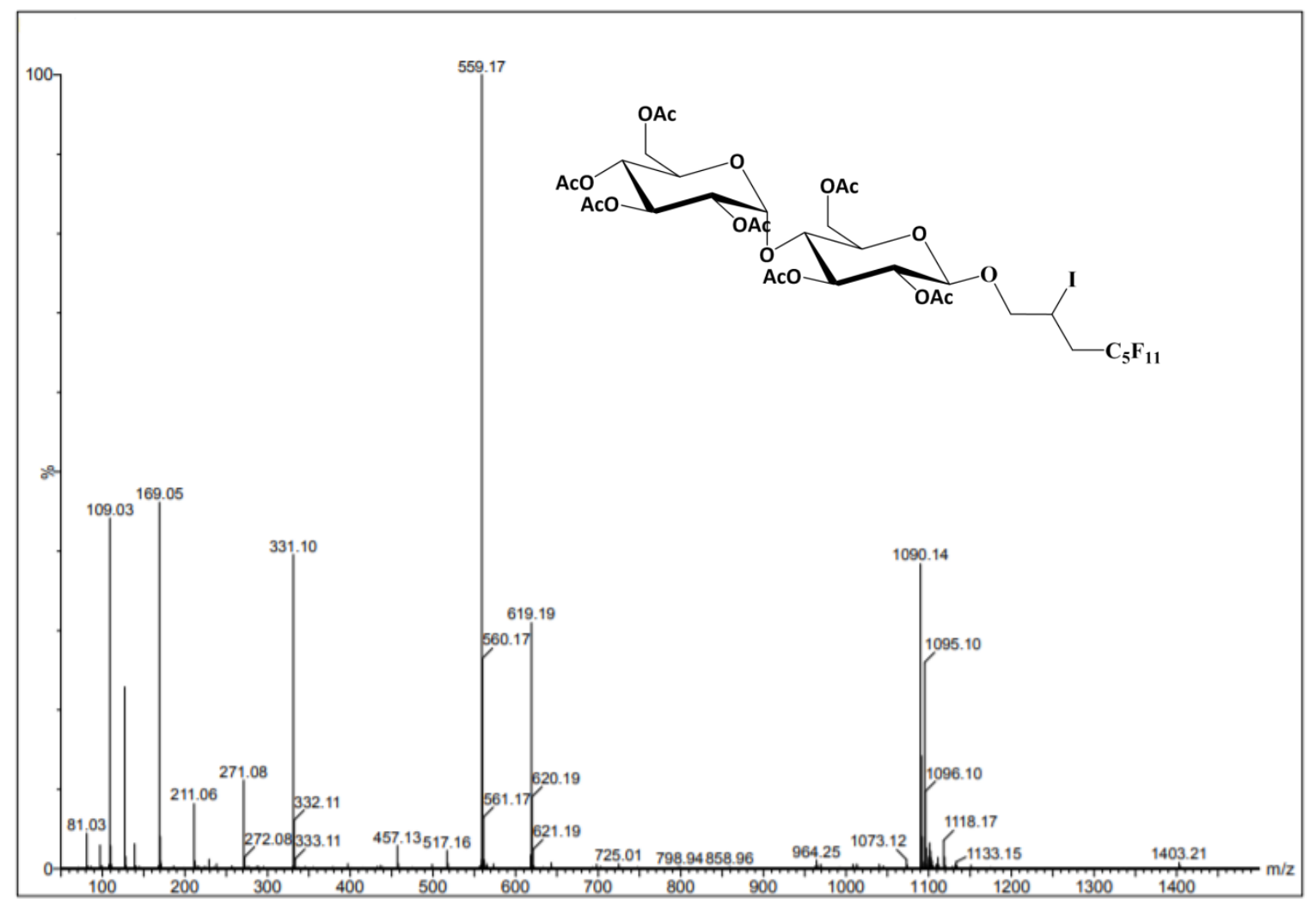

Figure S16. MS spectrum of compound 3a. 


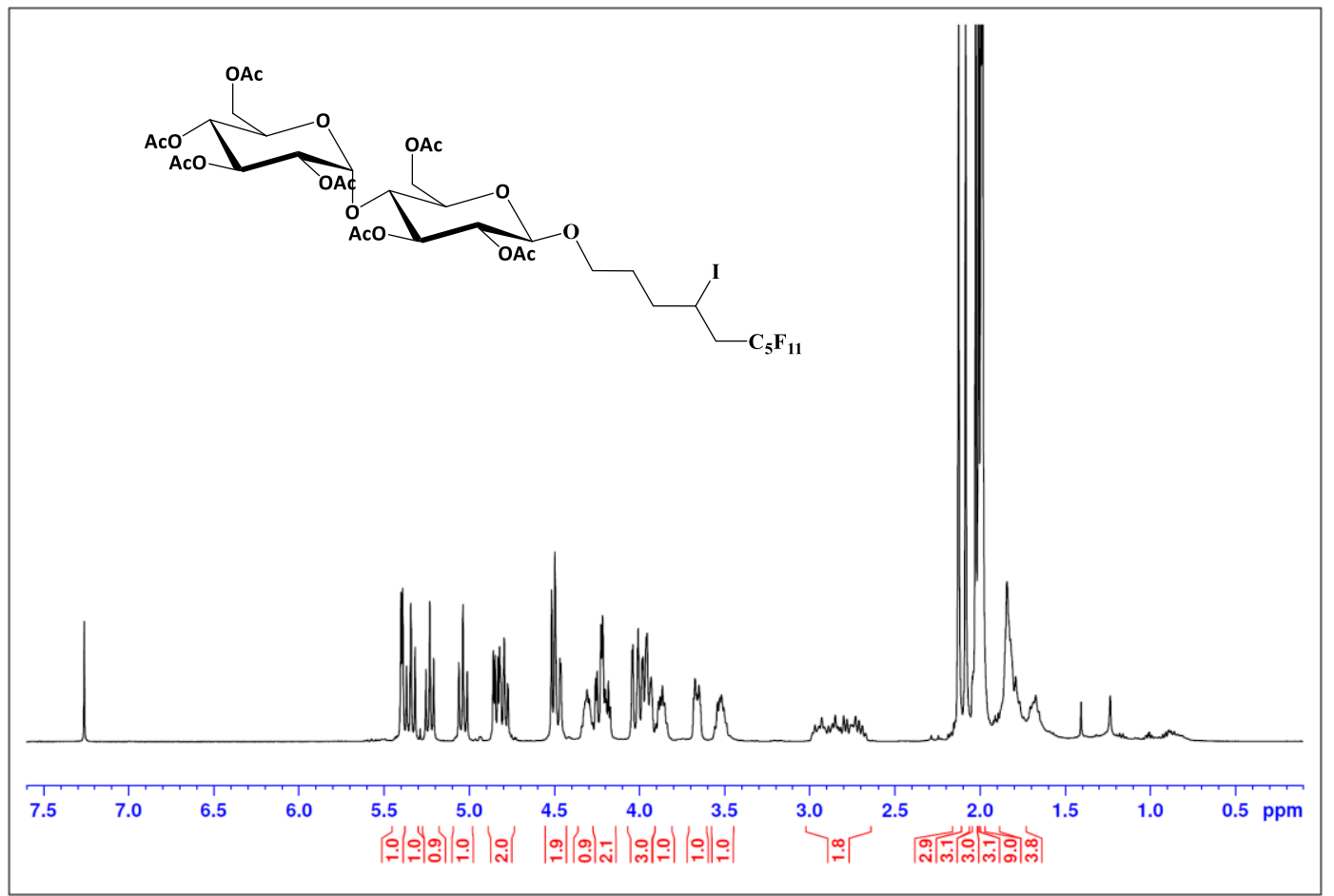

Figure S17. ${ }^{1} \mathrm{H}-\mathrm{NMR}$ spectrum of compound $\mathbf{3 b}$ in $\mathrm{CDCl}_{3}$.

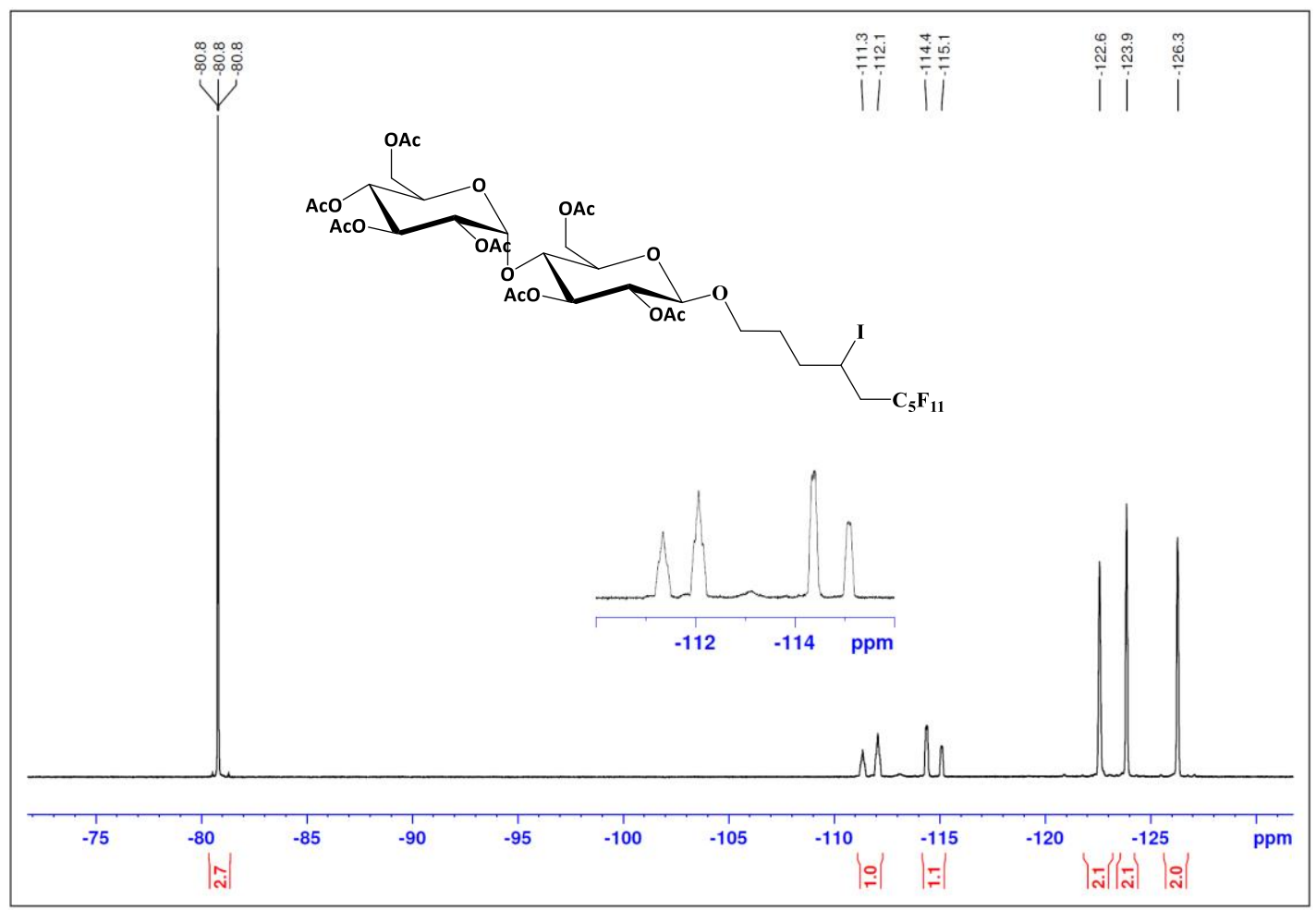

Figure S18. ${ }^{19} \mathrm{~F}-\mathrm{NMR}$ spectrum of compound $\mathbf{3 b}$ in $\mathrm{CDCl}_{3}$. 


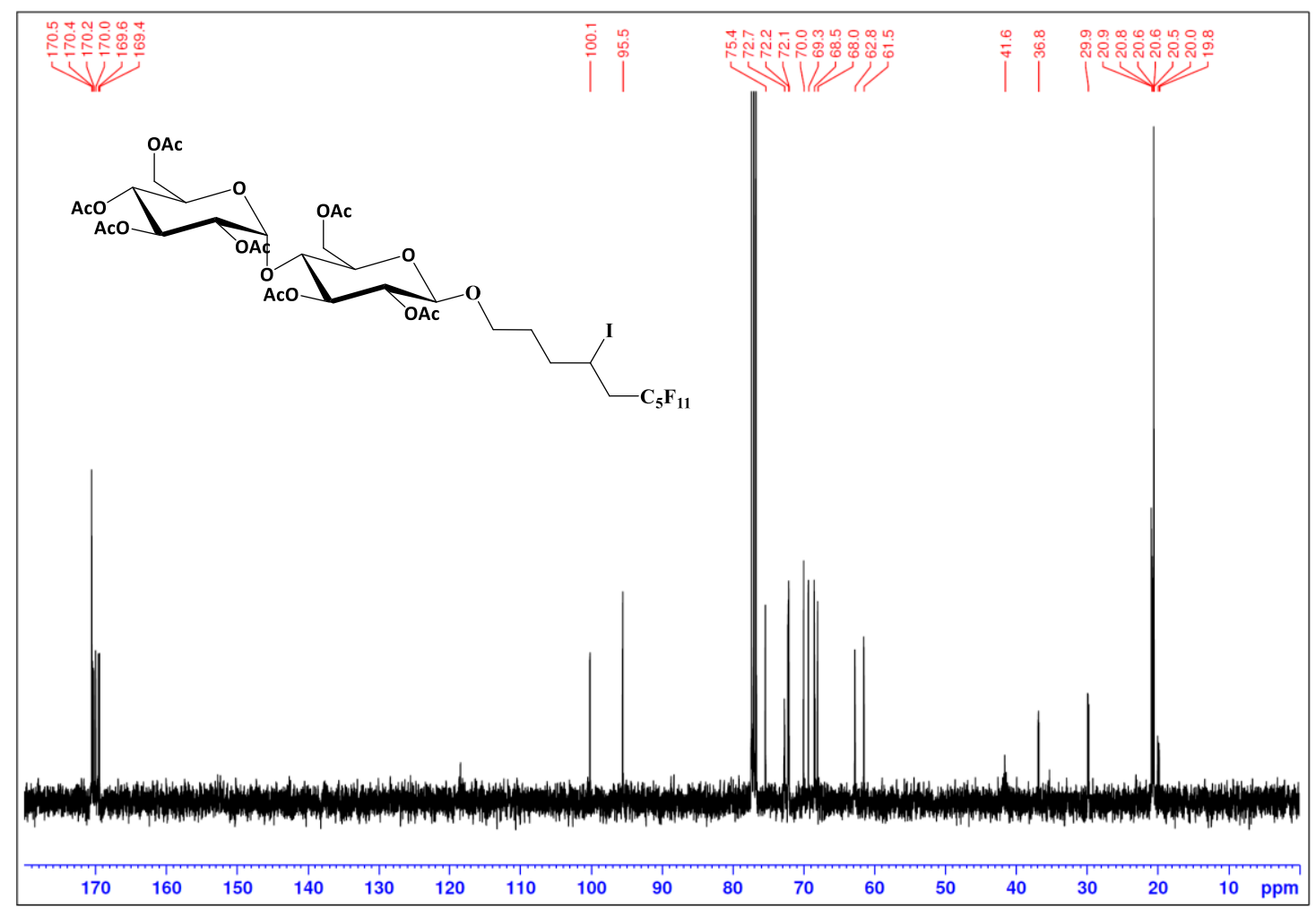

Figure S19. ${ }^{13} \mathrm{C}-\mathrm{NMR}$ spectrum of compound $\mathbf{3 b}$ in $\mathrm{CDCl}_{3}$.

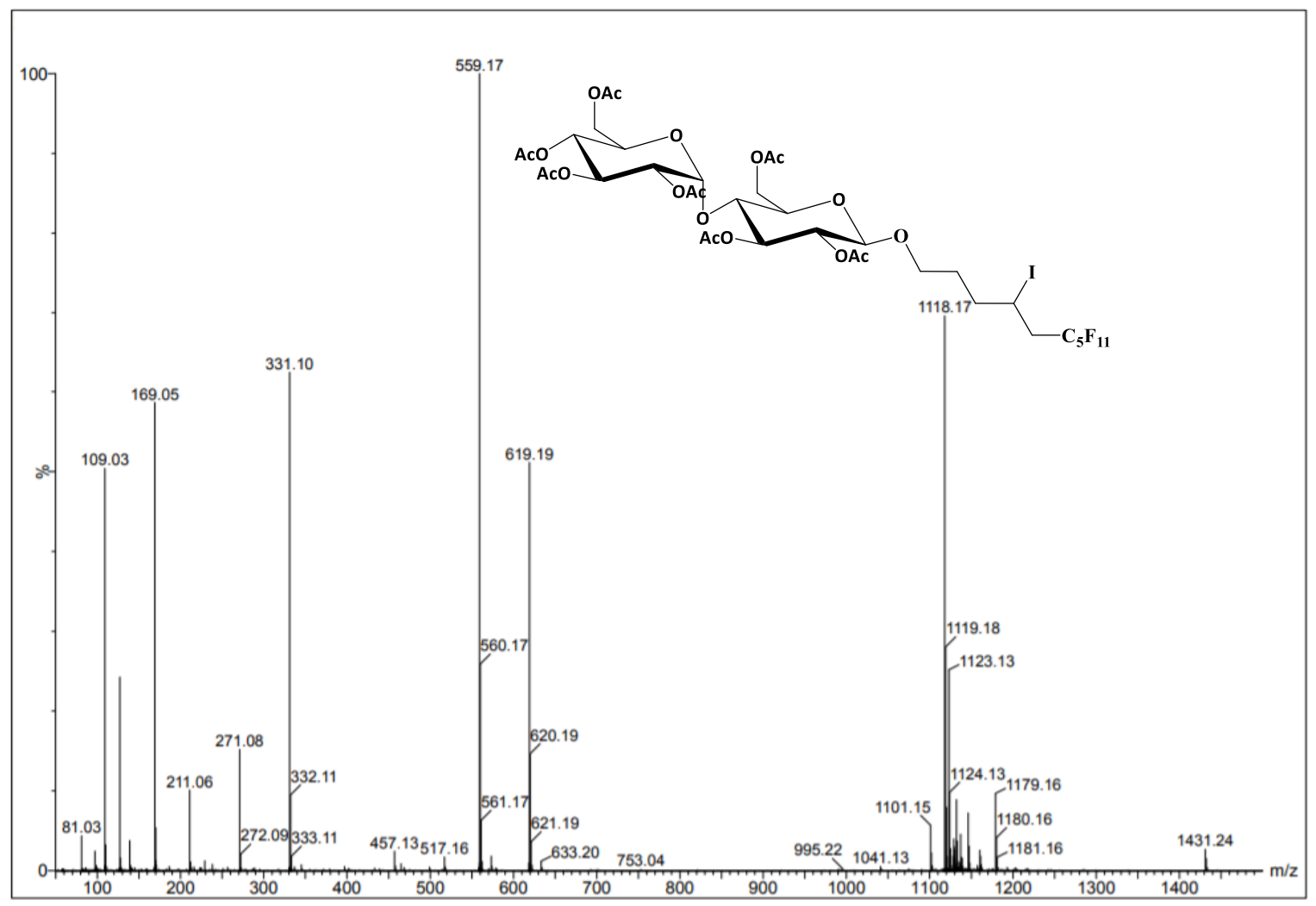

Figure S20. MS spectrum of compound 3b. 


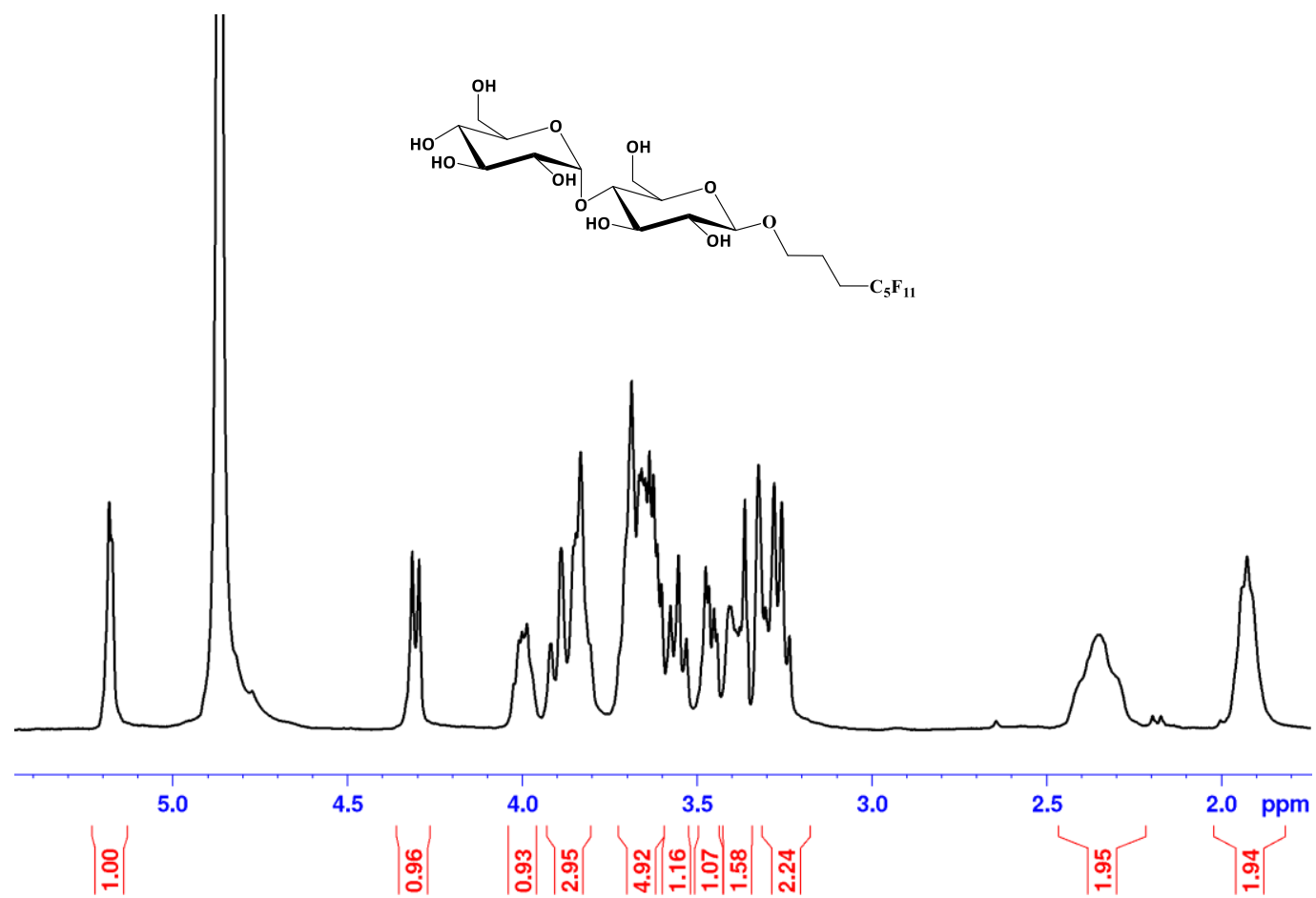

Figure S21. ${ }^{1} \mathrm{H}-\mathrm{NMR}$ spectrum of compound $4 \mathbf{a}\left(\mathbf{F}_{5} \mathrm{OM}\right)$ in $\mathrm{CD}_{3} \mathrm{OD}$.

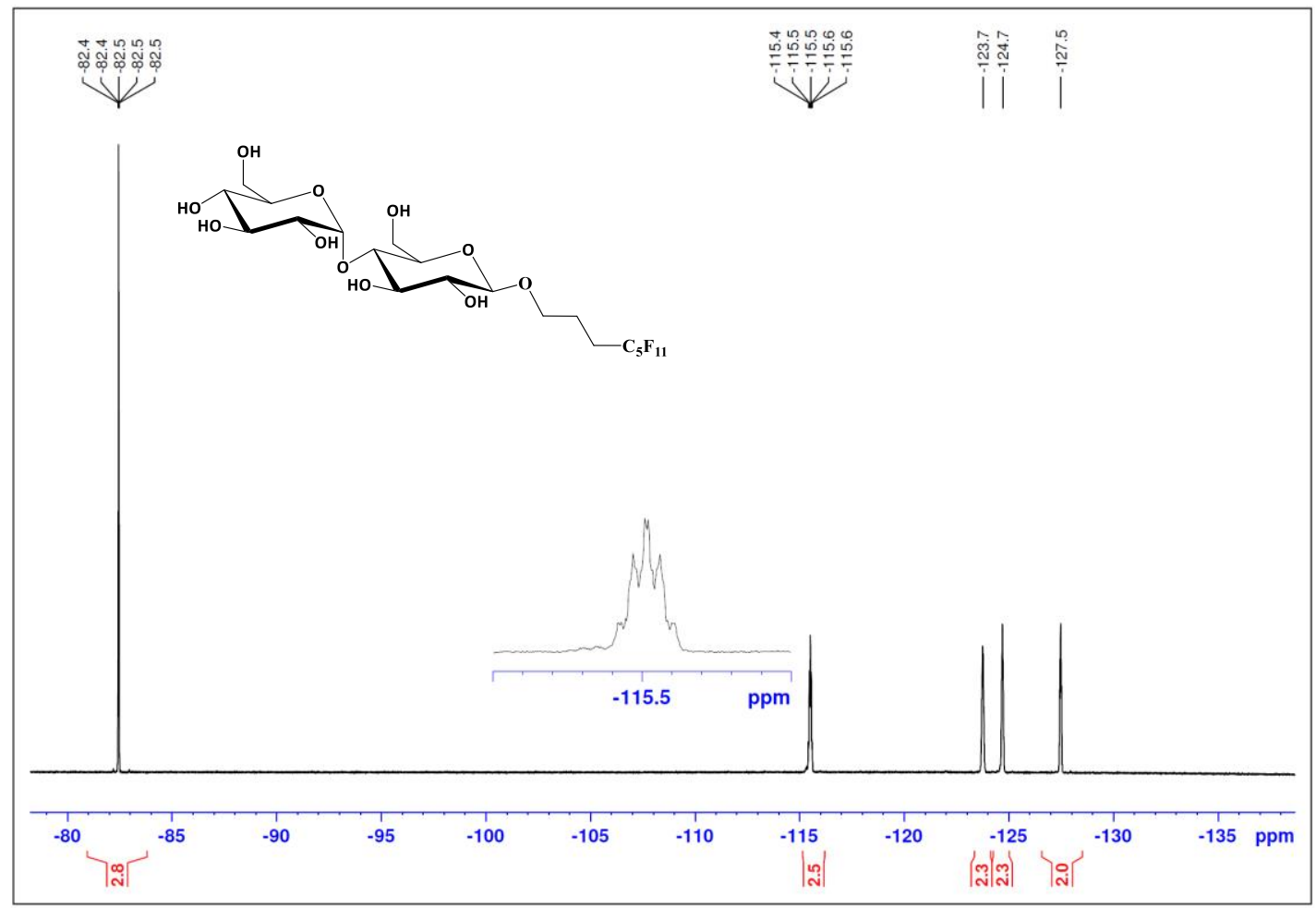

Figure S22. ${ }^{19}$ F-NMR Spectrum of compound $4 \mathbf{a}\left(\mathbf{F}_{5} \mathrm{OM}\right)$ in $\mathrm{CD}_{3} \mathrm{OD}$. 


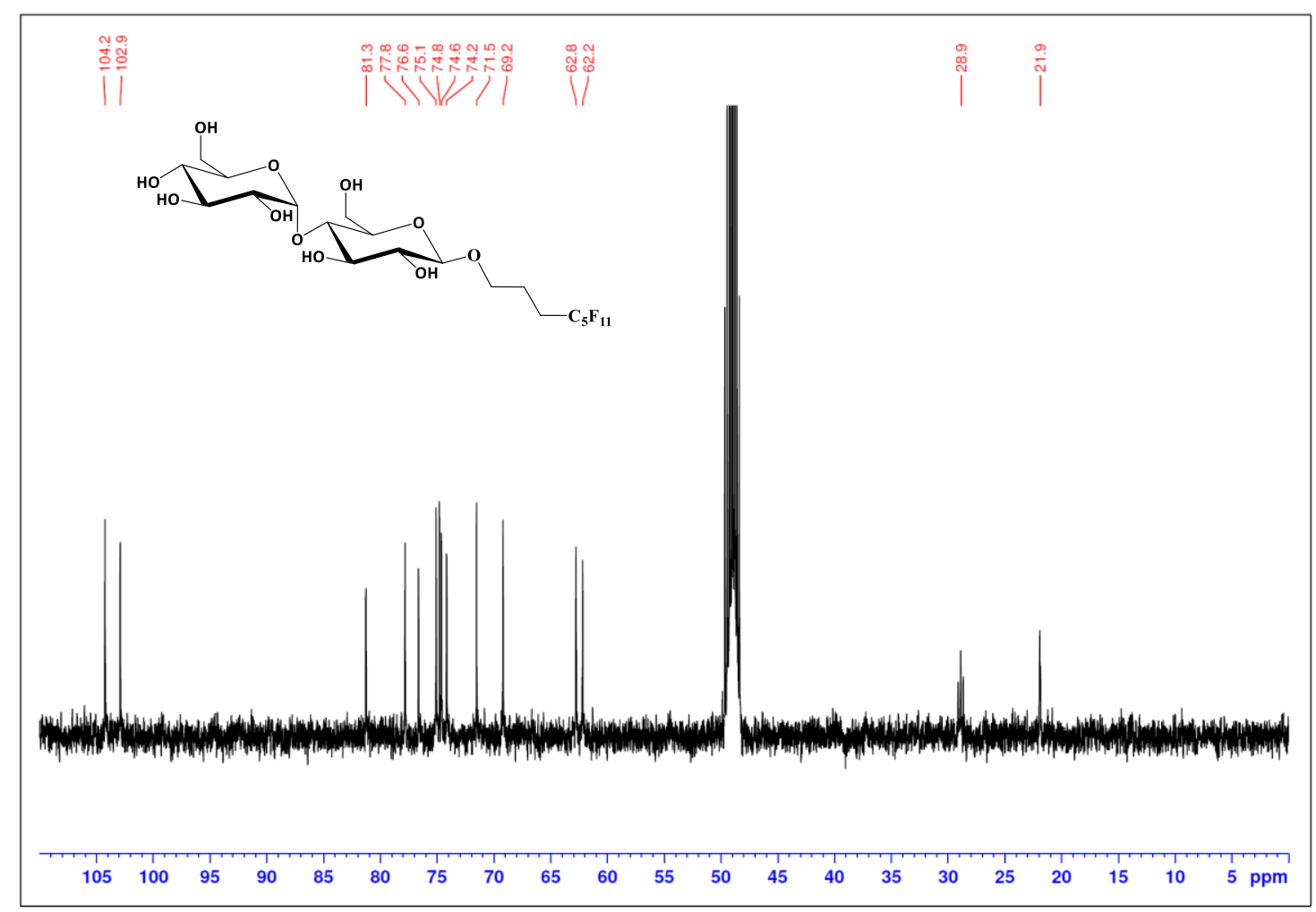

Figure S23. ${ }^{13} \mathrm{C}-\mathrm{NMR}$ Spectrum of compound $4 \mathbf{a}\left(\mathbf{F}_{5} \mathrm{OM}\right)$ in $\mathrm{CD}_{3} \mathrm{OD}$.

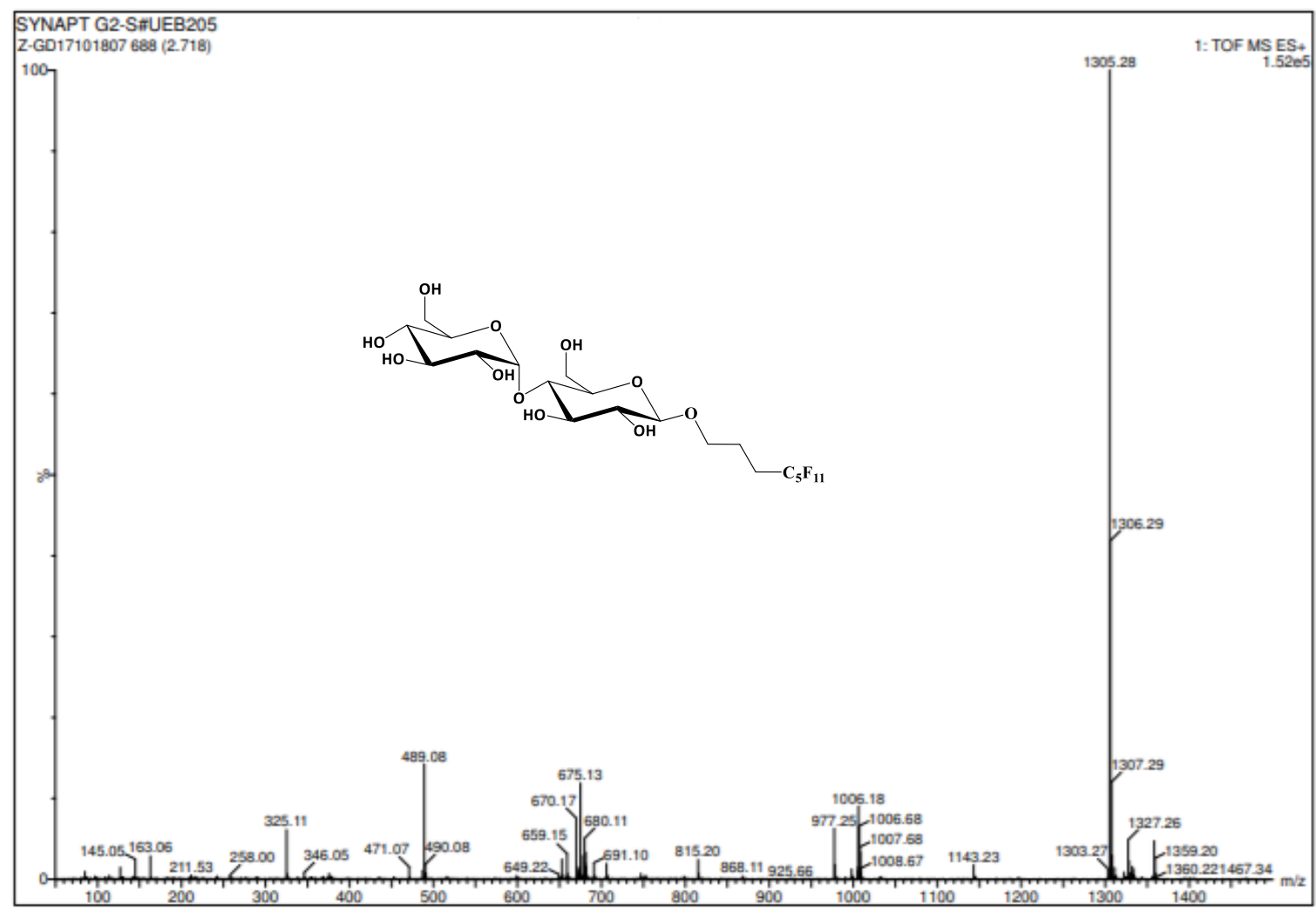

Figure S24. MS spectrum of compound $4 \mathbf{a}\left(\mathrm{F}_{5} \mathrm{OM}\right)$. 


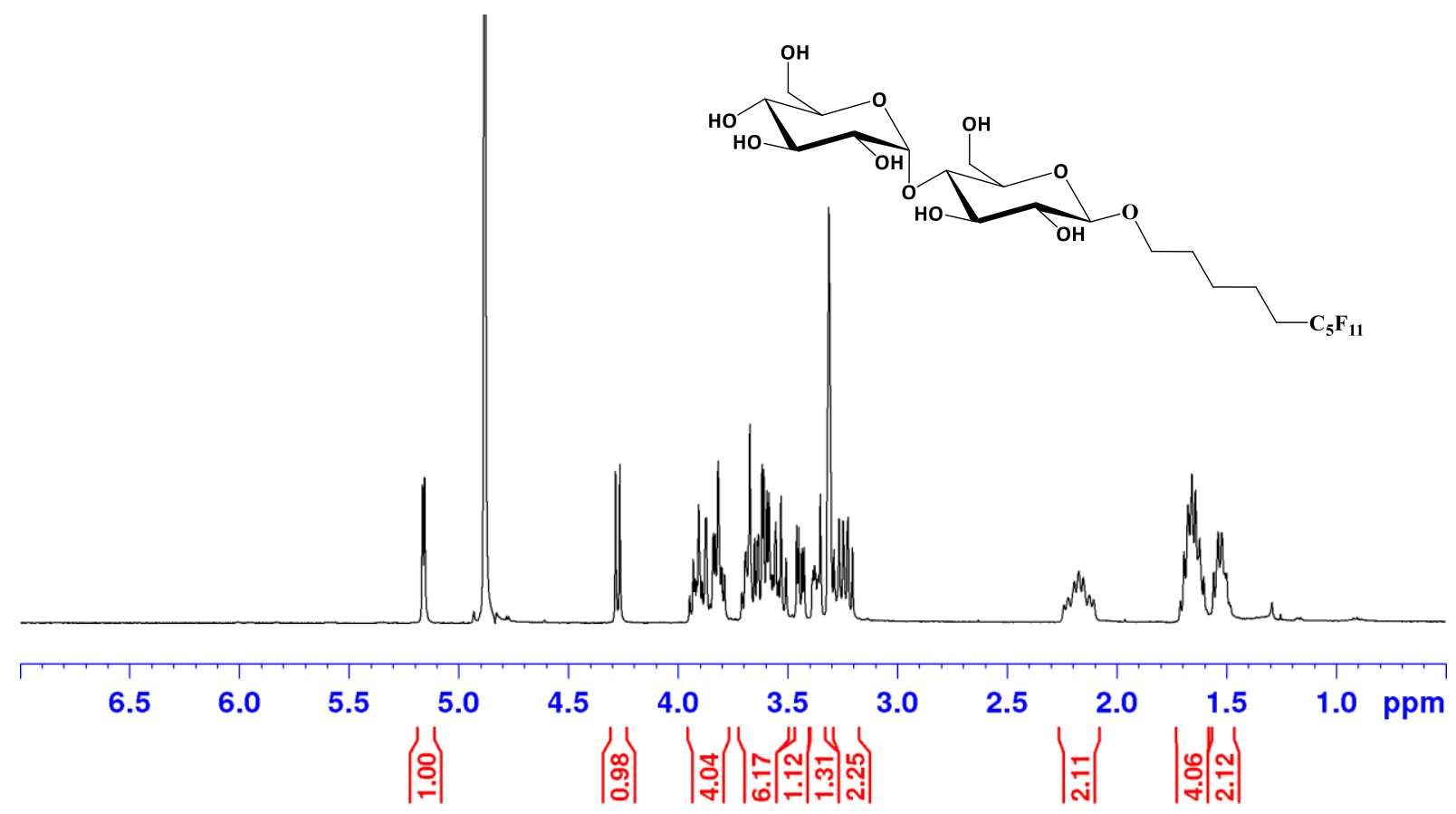

Figure S25. ${ }^{1} \mathrm{H}-\mathrm{NMR}$ Spectrum of compound $\mathbf{4 b}\left(\mathbf{F}_{5} \mathbf{D M}\right)$ in $\mathrm{CD}_{3} \mathrm{OD}$.

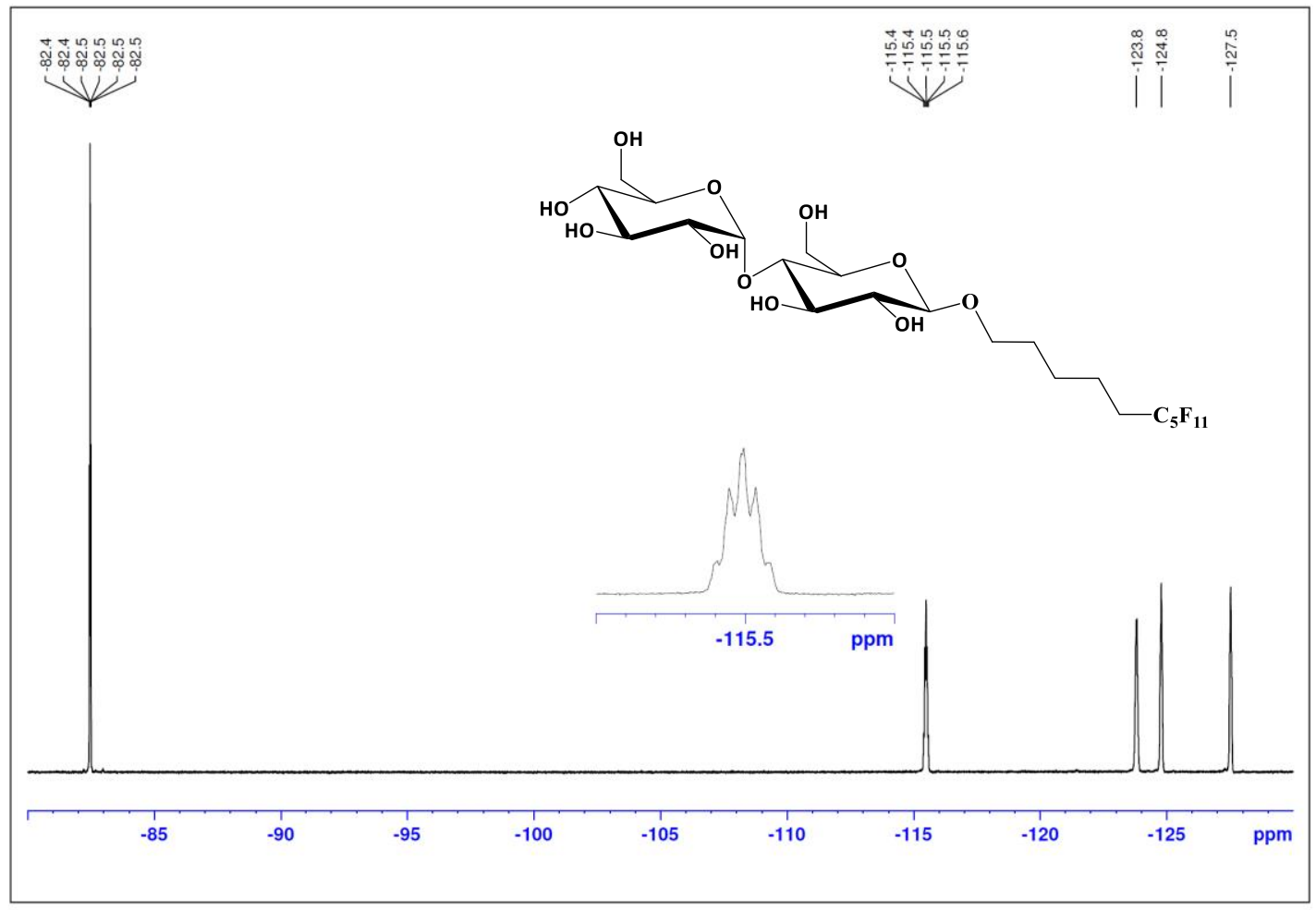

Figure S26. ${ }^{13}$ F-NMR Spectrum of compound $\mathbf{4 b}\left(\mathbf{F}_{5} \mathbf{D M}\right)$ in $\mathrm{CD}_{3} \mathrm{OD}$. 


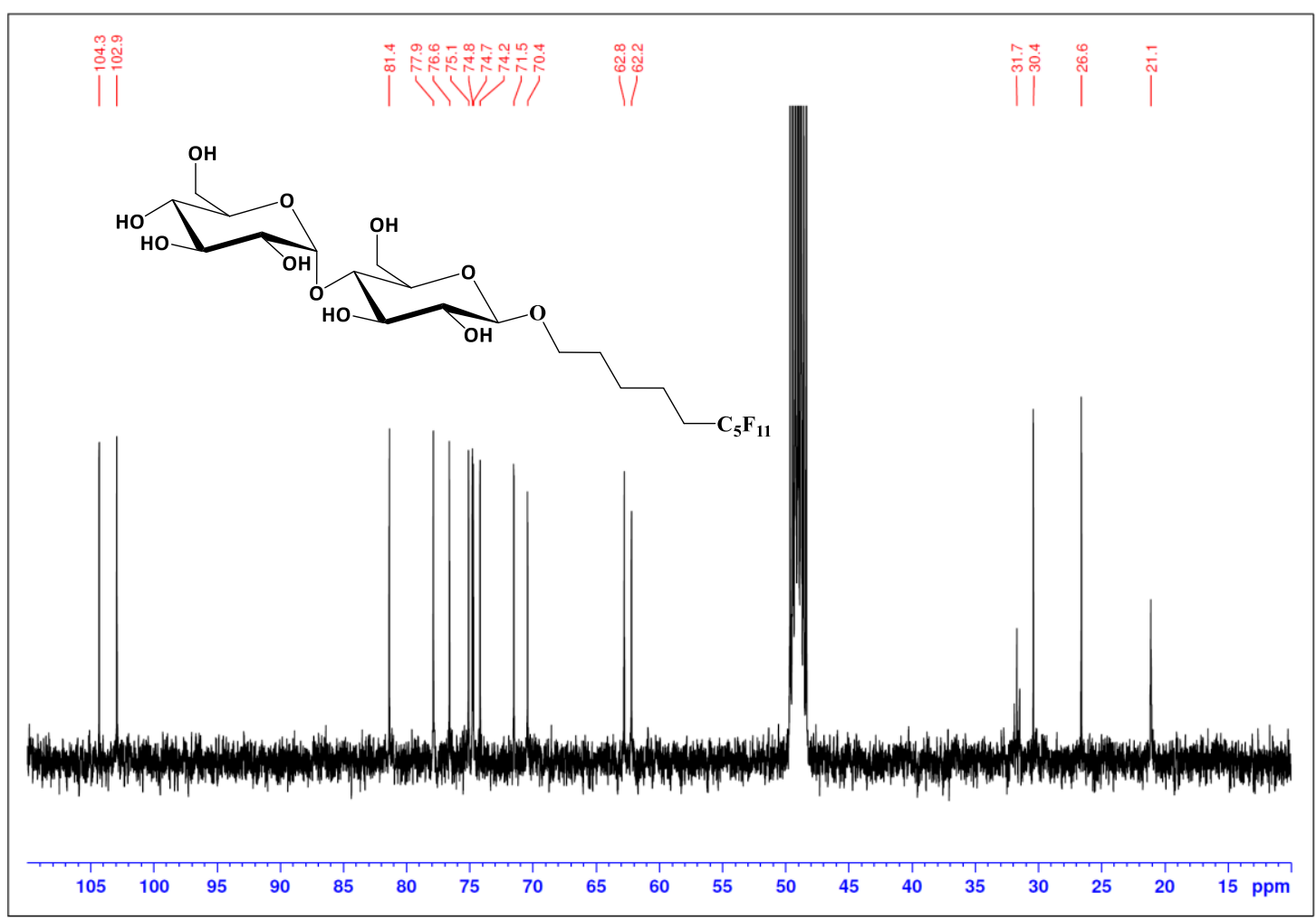

Figure S27. ${ }^{13} \mathrm{C}-\mathrm{NMR}$ Spectrum of compound $\mathbf{4 b}\left(\mathbf{F}_{5} \mathbf{D M}\right)$ in $\mathrm{CD}_{3} \mathrm{OD}$.

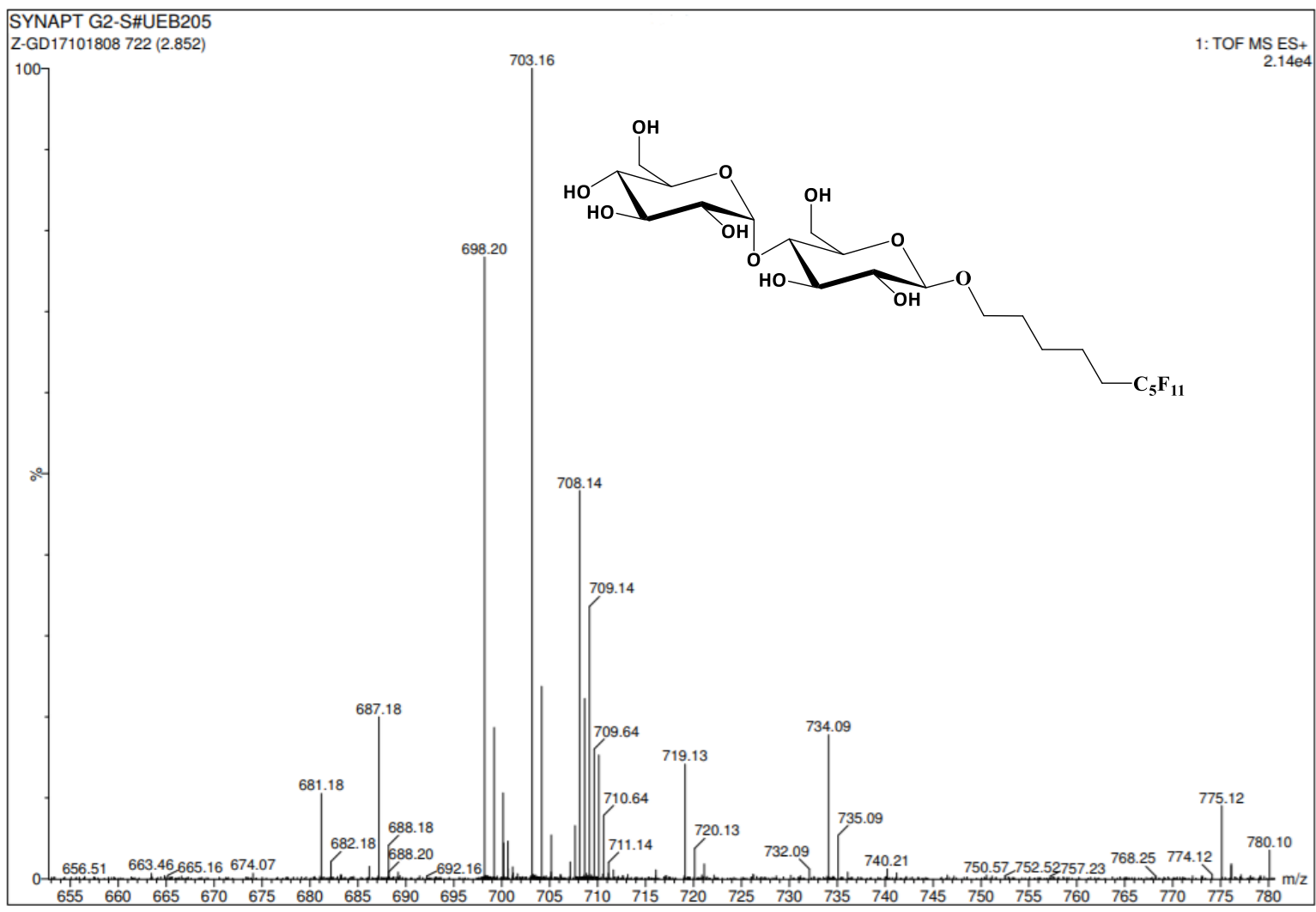

Figure S28. MS Spectrum of compound $4 \mathbf{b}\left(\mathbf{F}_{5} \mathbf{D M}\right)$. 


\section{References.}

1. Al-Soufi, W.; Piñeiro, L.; Novo, M., A model for monomer and micellar concentrations in surfactant solutions: application to conductivity, NMR, diffusion, and surface tension data. J. Coll. Interface Sci. 2012, 370 (1), 102-110.

2. Durchschlag, H.; Zipper, P., Calculation of Partial Specific Volumes and Other Volumetric of Detergents and Lipids. Jorn. Com. Esp. Deterg. 1995, 29, 275-292.

3. Durchschlag, H.; Zipper, P., Calculation of Partial Specific Volumes and Other Volumetric Properties of Small Molecules and Polymers. Journal of Applied Crystallography 1997, 30 (5-2), 803-807.

4. Mathieu, K.; Javed, W.; Vallet, S.; Lesterlin, C.; Candusso, M. P.; Ding, F.; Xu, X. N.; Ebel, C.; Jault, J. M.; Orelle, C., Functionality of membrane proteins overexpressed and purified from E. coli is highly dependent upon the strain. Sci Rep 2019, 9 (1), 2654.

5. $\quad$ Breyton, C.; Javed, W.; Vermot, A.; Arnaud, C.-A.; Hajjar, C.; Dupuy, J.; Petit-Hartlein, I.; Le Roy, A.; Martel, A.; Thépaut, M.; Orelle, C.; Jault, J.-M.; Fieschi, F.; Porcar, L.; Ebel, C., Assemblies of lauryl maltose neopentyl glycol (LMNG) and LMNG-solubilized membrane proteins. Biochimica et Biophysica Acta (BBA) - Biomembranes 2019, 1861 (5), 939-957. 